\title{
De la patria criolla a la historia de la nación
}

\author{
Enrique Florescano
}

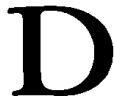
urante los dos primeros siglos del gobierno español proliferaron diversas interpretaciones del pasado, limitadas por una estrecha visión corporativa. Las órdenes mendicantes promovieron un relato que narraba su asentamiento en el país extraño, exaltaba la labor evangelizadora y elogiaba el ardor religioso de sus miembros. Las ciudades, comenzando por la capital del reino, mimaron a letrados distinguidos, quienes escribieron crónicas laudatorias del territorio, los monumentos y el talante de los pobladores. Los grupos étnicos, encerrados en los límites de la república de indios, elaboraron un relato pueblerino dedicado a proteger las tierras comunales y la identidad local. Se trata, como se advierte, de discursos ensimismados que ignoran la memoria del otro y expresan la profunda división que separaba a los pobladores de Nueva España en estamentos, grupos y etnias antagónicos. En estos años no había condiciones para imaginar una historia que comprendiera el conjunto del virreinato.

\section{EI PATRIOTISMO CRIOLLO}

Como lo mostraron los iluminadores estudios de Francisco de la Maza, Edrnundo O'Gorman, Luis Villoro, Luis Gon- zález y David Brading, los criollos, los descendientes de españoles e indios, fueron los primeros en afirmar su identidad recurriendo a una introspección en busca de los orígenes remotos. De ese río, que nace delgado en el siglo XVI con las primeras generaciones de gente criolla y se desborda en el XVIII, se distinguen tres avenidas: el establecimiento de lazos de identidad con la tierra que se habita, el rescate del antiguo pasado indígena para asentar en él la legitimidad de la patria que empieza a construirse y la creación de símbolos que encarnan los valores patrios.

Apropiarse física y culturalmente de la tierra extraña fue uno de los desafíos que primero se impuso a la gente criolla. A fines del siglo Xvil los criollos encontraton en la exuberante naturaleza americana y en el exótico pasado indígena dos elementos que los separaban de los españoles y afirmaban su identidad con la tierra de nacimiento. Imperceptiblemente, la tarea de reconocer y describir el territorio, un cometido que antes había recaído en los exploradores europeos, se volvió responsabilidad de los oriundos del país. Los criollos comenzaron a adentrarse en el conocimiento del territorio por vivencia directa, poseyéndolo y recorriéndolo, y más tarde, cuando se estrenaron de agrimensores en los innumerables 
pleitos de tierras suscitados por el nuevo acomodo de los campesinos en pueblos trazados a la española. Entonces se delinearon los primeros planos urbanos, caminos carreteros y cartas regionales, muchos de ellos elaborados por gente criolla. ${ }^{1}$

En las Relaciones geográficas que Felipe II mandó colectar hacia $1580 \mathrm{nu}$ merosos criollos colaboraron con los indios viejos y las autoridades virreinales para componer las relaciones y mapas de las aldeas de Nueva España. ${ }^{2}$ En el siglo XVIII la elaboración de unas Relaciones topográficas incrementó los conocimientos sobre la geografía del país. ${ }^{3}$ El siglo de la Ilustración fue también el de la ampliación de las fronteras del virreinato. Para frenar la expansión de los rusos en la costa del Pacífico y de los ingleses y franceses en la del Atlántico, una avanzada defensiva sembró presidios militares, misiones de religiosos, haciendas de minas y nuevos poblados en esos territorios dilatados.

La ampliación de la frontera norte coincidió con la era de los viajes de exploración científica y con el hábito de inventariar el territorio y clasificar la flora y la fauna. Los nuevos asenta-

\footnotetext{
${ }^{1}$ El programa de congregación de pueblos, la creación de las repúblicas de indios y del fundo legal, significaron en conjunto una reasignación de la tierra, una redistribución de la población indígena y el surgimiento de nuevos poblados. Todo esto se expresó en las nuevas demarcaciones, catastros, mapas, lienzos y descripciones de la tierra que se elaboraron entre 1530 y 1570.

2 Moreno Toscano, Geografía, 1968; Mundy, Mapping, 1996; Sacchi, Mappe, 1997. 1976.

3 Florescano y Gil Sánchez, Descripciones,
}

mientos, las expediciones científicas y las estrategias defensivas provocaron un alud de conocimientos que se tradujo en una nueva imagen del país. El mapa, un medio de comunicación que cobró auge en esos años, le dio una dimensión gráfica a esa imagen. En 1748 se publicó por primera vez en México el legendario mapa del territorio que desde el siglo pasado había elaborado don Carlos de Sigüenza y Góngora. Más tarde, José Antonio Alzate le agregó nuevos datos y en 1768 lo dedicó a la Real Academia de Ciencias de París (fig. 1). 4

En 1779 el ingeniero Miguel Constanzó diseñó un plano para señalar las divisiones políticas del virreinato y las nuevas demarcaciones de la parte norte, llamadas Provincias Internas. Estos planos y cartas por primera vez mostraron a los novohispanos la extensión grandiosa que había alcanzado el territorio de su patria (fig. 2). No es un azar que los primeros autores del mapa general de Nueva España fueran gente criolla, como Carlos de Sigüenza y Góngora y José Antonio Alzate. También fueron criollos quienes suministraron a Alejandro de Humboldt la información más actualizada para componer su Atlas de Nueva España. Según Manuel Orozco y Berra, este mapa

vino a ser como el resumen de los adelantamientos geográficos de la colonia, la última expresión de lo que el gobierno y los habitantes de Nueva España habían ejecutado para conocer la topografía del país (fig. 3). ${ }^{5}$

${ }^{4}$ Orozco y Berra, Apuntes, 1973, pp. 326-334.

s Ibid., p. 341. 


\section{SECUENCIA}

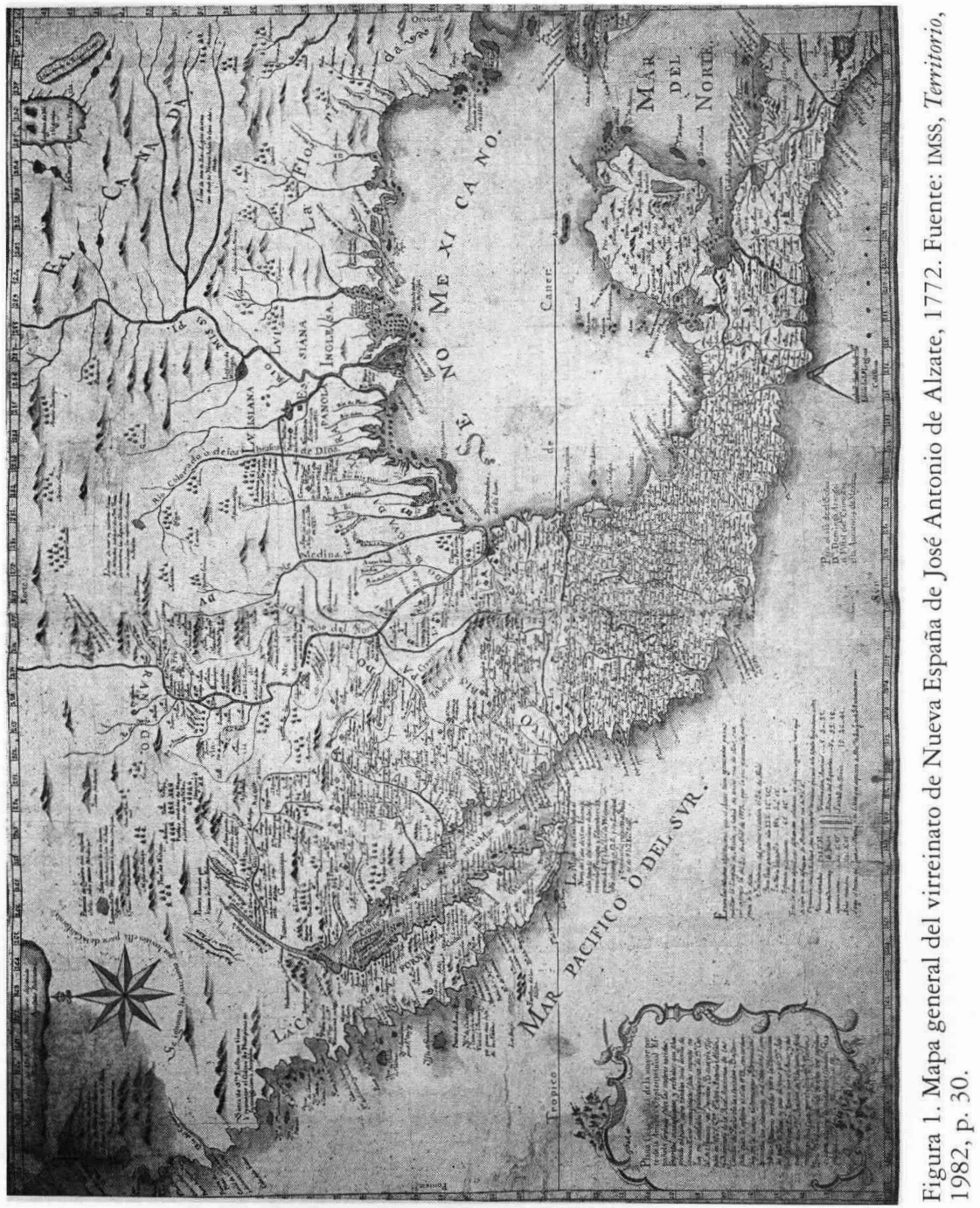




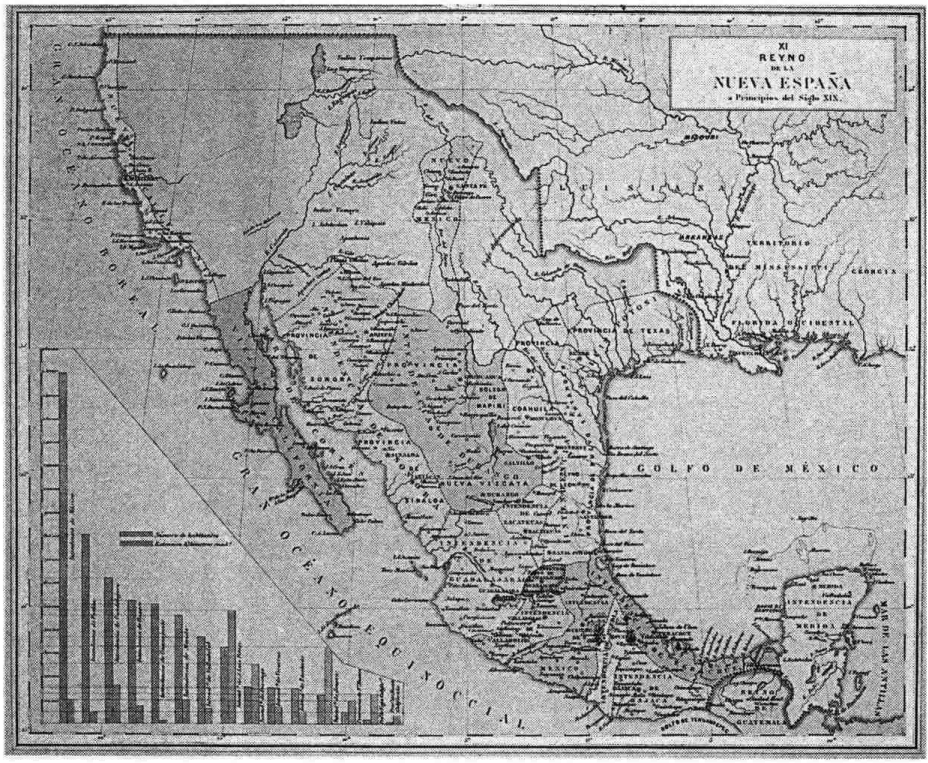

Figura 2. Mapa del reino de Nueva España con sus divisiones administrativas. Fuente: IMSs, Territorio, 1982.

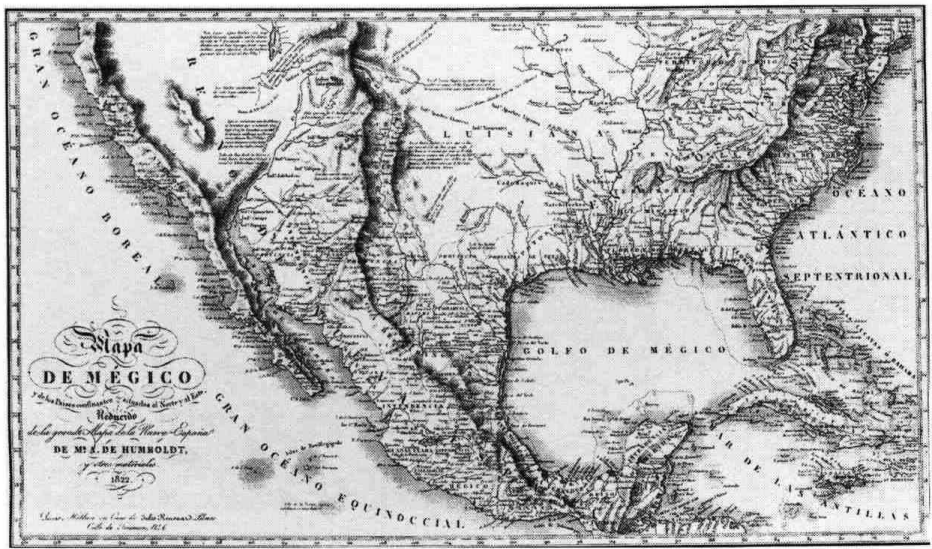

Figura 3. Mapa general del reino de Nueva España. Fuente: IMSs, Territorio, 1982. 
Con una fuerza visual inusitada, el mapa transmitió a los novohispanos la diversidad de un territorio dilatado, la cornucopia agrícola, minera, industrial y comercial contenida en sus fronteras, y la sensación de que un hado providencial protegía a la patria criolla. Como observó Manuel Orozco y Berra, los pobladores de Nueva España estaban convencidos de que el siglo XVIII había sido la época de su esplendor:

El siglo brillante de la colonia fue el xviII. Mejorada muy mucho la administración con autoridades ilustradas que comprendieron bien las ventajas que podían sacarse de generalizar las ciencias, nada tuvo de extraño que éstas florecieran hasta donde podían permitirlo las circunstancias excepcionales de Nueva España. Los métodos de enseñanza cambiaron; los establecimientos públicos se perfeccionaron; se procuró el cultivo particular de las ciencias físicas y matemáticas, y la Escuela de Minas fue un grandioso monumento levantado a las exigencias de las luces del siglo. El gobierno tomó por su cuenta las exploraciones de altura para reconocer las costas noroeste del continente, de donde resultó esa serie de viajes científicos, aún no bien conocidos y estimados; las costas del Golfo fueron registradas de nuevo, perfeccionando su hidrografía, y llevándola hasta puntos antes poco menos que ignorados. Quedó atravesado y recorrido el país en muchas direcciones, ya por peritos que fijaban los lugares por métodos exactos con instrumentos perfeccionados, ya por personas menos entendidas, que sin embargo daban a conocer la configuración dèl terreno. Se practicaron observaciones astronómicas delicadas y felices [...] la topo- grafía tomó un vuelo desacostumbrado, y fuera de los mapas particulares de las provincias y de las intendencias, virreyes ilustrados como Bucareli y Revillagigedo hicieron construir cartas generales con las antiguas o con las nuevas divisiones políticas adoptadas. Por su parte, los particulares dieron un contingente cuantioso, y la geografía tuvo más incrementos en el último tercio del siglo, que en todos los tiempos precedentes. ${ }^{6}$

\section{EL RESCATE DEL PASADO INDÍGENA}

La identidad con el territorio se complementó con el vínculo con el pasado. En el siglo XVII Carlos de Sigüenza y Góngora, Juan de Torquemada y Agustín de Vetancurt formaron colecciones de antigüedades indígenas, rescataron tradiciones orales y elogiaron las cualidades de la naturaleza americana. En la Monarquía indiana del franciscano Juan de Torquemada, publicada en 1615, el pasado mesoamericano fue ascendido a la categoría de una antigüedad clásica. En esta obra Torquemada recogió el saber acumulado por sus antecesores (Andrés de Olmos, Motolinía, Diego Durán, Bernardino de Sahagún y Gerónimo de Mendieta), y con esos conocimientos compuso una suma del pasado y las tradiciones de los nativos del país que gozó de fama en su tiempo y tuvo gran influencia más tarde. Sin embargo, Torquemada mantuvo la concepción denigratoria que hasta entonces había impedido la recuperación de ese pasado: la idea de que la re-

${ }^{6}$ Ibid. 
ligión y las obras que expresaban esa cultura eran producto del demonio.

Sorpresivamente esa imagen satánica comenzó a cambiar a mediados del siglo XVIII. Un signo revelador del aprecio que ahora merecía el pasado mesoamericano se condensó en la extraordinaria colección de antigüedades mexicanas reunida por Lorenzo Boturini entre 1736 y 1743 . Antes que colectar cacharros o piedras labradas, la obsesión del viajero italiano fue recoger las pictografías y códices donde se había resumido el pasado de los pueblos aborígenes. Para Boturini estos documentos contenían "tanta excelencia de cosas sublimes, que me atrevo a decir, que no sólo puede competir esta historia con las más célebres del orbe, sino excederlas". 7

Una circunstancia externa reactivó el interés por las identidades de la patria criolla. Entre 1749 y 1780 algunos de los autores más influyentes de la Ilustración europea (el conde de Buffon, el abate Raynal, Cornelius de Pauw y el historiador escocés William Robertson), escribieron páginas denigratorias sobre la naturaleza americana y advirtieron una incapacidad natural de los oriundos de América para crear obras de cultura y ciencia. ${ }^{8}$ Los primeros en responder a estos ataques fueron los religiosos y letrados criollos que se habían distinguido por alentar una interpretación positiva del pasado mesoamericano y por afirmar las virtudes creativas de los nacidos en América. Así, Juan José Eguiara y Eguren respondió a esas invectivas con una Bibliotheca mexicana (1755), una

\footnotetext{
7 Boturini, Idea, 1974, p. 31.

${ }^{8}$ Gerbi, Disputa, 1960.
}

obra monumental consagrada a mostrar los méritos de la producción científica y literaria de los mexicanos desde los tiempos más antiguos hasta las primeras décadas del siglo XVIII. ${ }^{9}$

Más tarde un jesuita criollo, Francisco Javier Clavijero, exilado en Italia y nostálgico de la patria, desbarató con argumentos elegantes las críticas de los ilustrados europeos y tornó el extraño pasado indígena en fundamento prestigioso de la patria criolla. Clavijero echó mano de la dialéctica del pensamiento ilustrado para atacar las tesis prejuiciadas de los críticos europeos y construir la primera imagen integral y elogiosa del pasado indígena. Partió de la igualdad de la naturaleza humana y de los valores de la antigüedad clásica como base de su análisis, y con estas armas destruyó la tesis sobre "la inferioridad natural" de los americanos que alegaban los críticos ilustrados, y descalificó las juicios acerca de la intervención del demonio que habían servido a los frailes para condenar la civilización indígena. ${ }^{10}$

Su Storia antica del Messico (1780) transformó el borroso pasado mexicano en una imagen luminosa que permitía reconocer una realidad hasta entonces inaprensible. En esta obra Clavijero dio el paso más difícil en el complejo proceso que por más de dos siglos perturbó a los criollos para fundar su identidad: asumió ese pasado como propio, como raíz sustantiva de su patria. Cla-

9 Millares, Juan, 1957.

10 Sobre el sentido de la obra de Clavijero véase Villoro, Grandes, 1950; Brading, Orígenes, 1980; Clavijero, Antología, 1976, y Pacheco, "Patria", 1976. 
vijero es el primer historiador que presenta una imagen armoniosa del pasado indígena y el primer escritor que rechaza el etnocentrismo europeo y afirma la independencia cultural de los criollos mexicanos. Otra aportación suya fue abrirle un dilatado horizonte a la noción de patria: al rescatar la originalidad del pasado mesoamericano, la patria criolla adquirió los prestigios del pasado remoto y se proyectó hacia el futuro con una dimensión política extraordinaria. ${ }^{11}$

Bajo estas motivaciones el rescate del pasado indígena se aceleró en las últimas décadas del siglo XVIII. Por los años en que Clavijeto escribía su Historia, Mariano Veytia, un criollo admirador de Boturini, compuso una Historia antigua de México que se publicó más tarde. José Antonio Alzate, el famoso editor de las Gazetas de literatu$\mathrm{ra}$, se interesó también en los monumentos antiguos. Pensaba que un "edificio manifiesta el carácter y cultura de las gentes", y se atrevió a decir que podía arrojar luz sobre el "origen de los indios". Con esas miras publicó un artículo donde por primera vez describió los monumentos arqueológicos del Tajín, y más tarde dio a conocer sus $A n$ tiguiedades de Xochicalco (1791), que es la primera publicación ilustrada con estampas de una ciudad antigua. Los estudios sobre los monumentos históricos fructificaron en la obra de Antonio de León y Gama, Descripción bistórica y cronológica de las dos piedras (1792), un innovador análisis de la Coatlicue y la Piedra del Sol, los monolitos encontrados en la plaza mayor de la ciudad

11 Florescano, Memoria, 1994, pp. 470-473. de México en 1790. En su estudio de la Piedra del Sol, León y Gama impuso una marca en las investigaciones arqueológicas. Por primera vez un monumento arqueológico sirvió de apoyo para explicar todo un sistema de ideas. $\mathrm{Y}$ en contra de las corrientes en boga, puso en claro que el calendario indígena se regía por conceptos propios y no podía explicarse con las categorías del calendario europeo. ${ }^{12}$

El interés por las antiguas civilizaciones americanas se extendió a un campo entonces ignorado: la exploración de las ciudades y monumentos arqueológicos. En 1773 se organizó una expedición a Palenque y en 1784 se dieron a conocer los primeros informes y dibujos sobre una zona de monumentos antiguos. Más tarde, Carlos III ordenó realizar nuevas exploraciones en esa región, y Carlos IV continuó esta política y apoyó una expedición, dirigida por Guillermo Dupaix y el dibujante mexicano Luciano Castañeda, que entre 1805 y 1807 recorrió el centro y el sureste del virreinato, reunió una importante colección de piezas arqueológicas y redobló el interés por el conocimiento de las antigüedades. ${ }^{13}$

Alejandro de Humboldt visitó en 1803 una Nueva España en proceso de transformación. En ese año intenso, pleno de recorridos, asombros y descubrimientos, el sabio alemán viajó por el norte minero, visitó las principales regiones y monumentos del centro del país, subió a los picos más altos y en todos lados realizó mediciones cientí-

12 Ibid.

13 Bernal, Historia, 1979, p. 86; Alcina, Arqueólogos, 1995. 
ficas con aparatos modernos, estudió la geografía, la flora y las antigüedades y acopió una información pasmosa sobre el medio físico, la población, la riqueza minera, las actividades económicas y la organización administrativa y política del virreinato. En su Ensayo político sobre el reino de la Nueva España o en sus Vistas de las cordilleras y monumentos de los pueblos indígenas de América, presentó la imagen de un país inmenso, hasta entonces falto de un cuadro elocuente que mostrara su verdadera dimensión. La visión grandiosa que aparece en esas obras era en buena medida la imagen optimista que los criollos se habían hecho de su patria y le habían transmitido al sabio alemán. ${ }^{14}$

\section{LOS SÍMBOLOS DE LA PATRIA CRIOLLA}

A mediados del siglo XVIII la imagen del país pujante se unió con la imagen de un país antiguo protegido por la divinidad. Después de los viajes de Colón se acostumbró distinguir los cuatro continentes con la figura de una mujer engalanada con los atributos propios de su región. Pero en contraste con las hermosas figuras de Europa, África y Asia, América fue representada por una mujer desnuda, portando flechas y atuendos primitivos (fig. 4). Los criollos de las posesiones españolas en América rechazaron esa imagen salvaje y desde los siglos XVII y XVIII dibujaron la América y sus naciones con la prestancia de una mujer indígena atractiva y ricamente ataviada. Los novohispanos le agrega-

\footnotetext{
14 Véase, Humboldt, Ensayo, 1966; Miranda, Humboldt, 1962, y Labastida, Humboldt, 1999.
}

ron a esta imagen el escudo de armas de la antigua Tenochtitlán, el signo que ubicaba a la mujer hermosa en la tierra mexicana (fig. 5).

En esta guerra de imágenes el escudo de armas del antiguo reino mexicano fue persistentemente repudiado por las autoridades virreinales y sustituido por otros emblemas (fig. 6). Sin embargo, en la lucha por encontrar símbolos representativos de las nuevas identidades que se estaban forjando en América, los criollos y los mestizos adoptaron el emblema del águila parada sobre un nopal y combatiendo a la serpiente y progresivamente lo fueron imponiendo en las representaciones que simbolizaban lo más entrañable de la patria. En los documentos oficiales el emblema indígena poco a poco usurpa el lugar del escudo hispano impuesto por Carlos V a la ciudad de México (fig. 7).

Las crónicas que los criollos escribieron para celebrar a la ciudad y recordar su historia antigua se distinguen por llevar en su portada o en sus láminas las insignias del antiguo reino azteca. En la segunda mitad del siglo XVIII esta insignia invade los mapas y planos que representan a la ciudad o al reino (fig. 8), y se instala en los monumentos que denotan lo propio del país. Este avance irresistible llegó al mismo corazón de la Iglesia, la institución que primero lo había expulsado como símbolo pagano. ${ }^{15}$ En el libro dedicado al primer santo mexicano (Vida de San $\mathrm{Fe}$ lipe de Jesús, 1802), aparece el emblema del águila como el símbolo que delata la mexicanidad del santo (fig. 9).

is Desarrollo estas ideas con amplitud en Florescano, Bandera, 1998. 


\section{SECUENCIA}

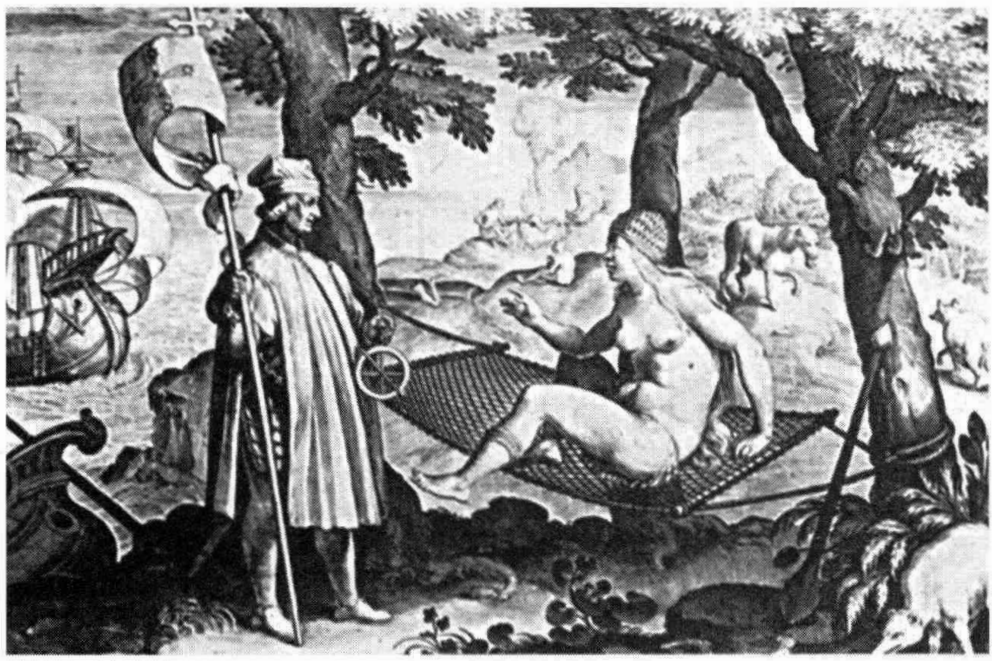

Figura 4. Américo Vespucio "descubre" América (india desnuda con plumas en la cabeza). Fuente: Honour, L'Amerique, 1975, p. 88.

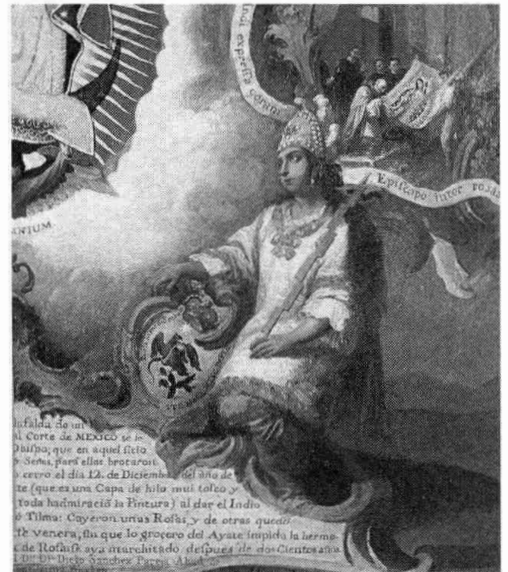

Figura 5. Alegoría de la Nueva España en un grabado de Joseph Sebastian y Johann Baptist Klauber, siglo XVIII. Fuente: Cuadriello, "Jeroglíficos", 1994, p. 109.

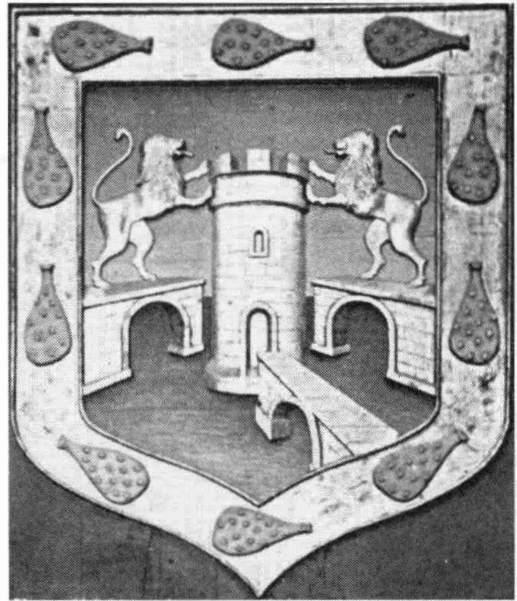

Figura 6. Escudo de armas de la ciudad de México otorgado por Carlos V. Fuente: La gran ciudad de México, 1970. 

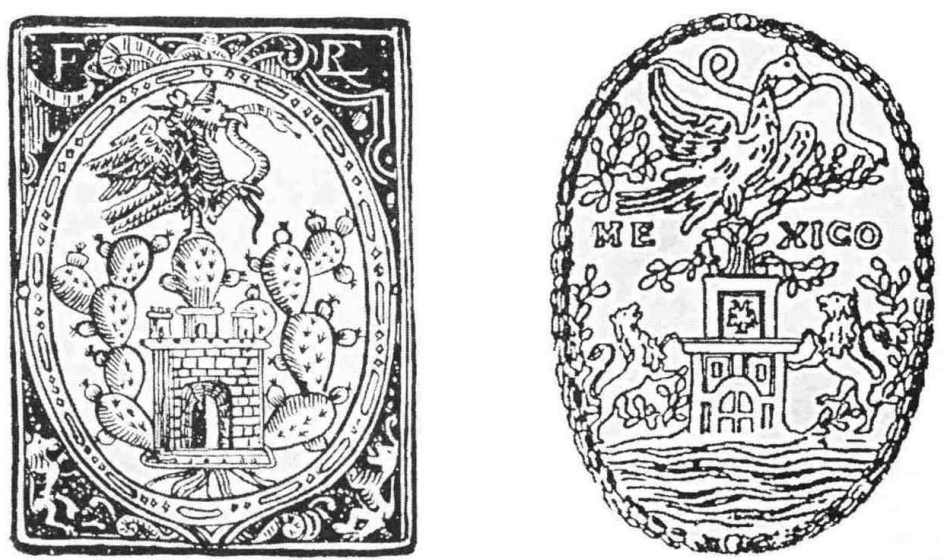

Figura 7. Dos imágenes: emblema de la ciudad de México según las Ordenanzas de 1663 y sello del Ayuntamiento de la ciudad de México. Fuente: Florescano, Bandera, 1998, p. 51.

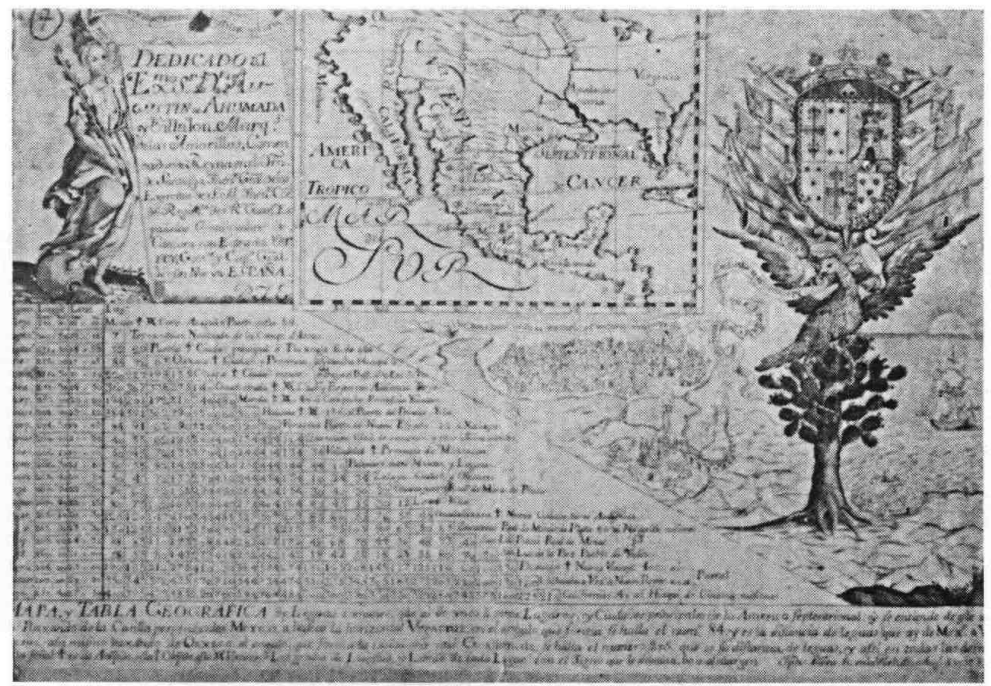

Figura 8. Mapa de América septentrional dedicado al marqués de las Amarillas; el escudo de armas del virrey descansa sobre las alas extendidas del águila parada en el nopal. Museo Nacional de Historia. 


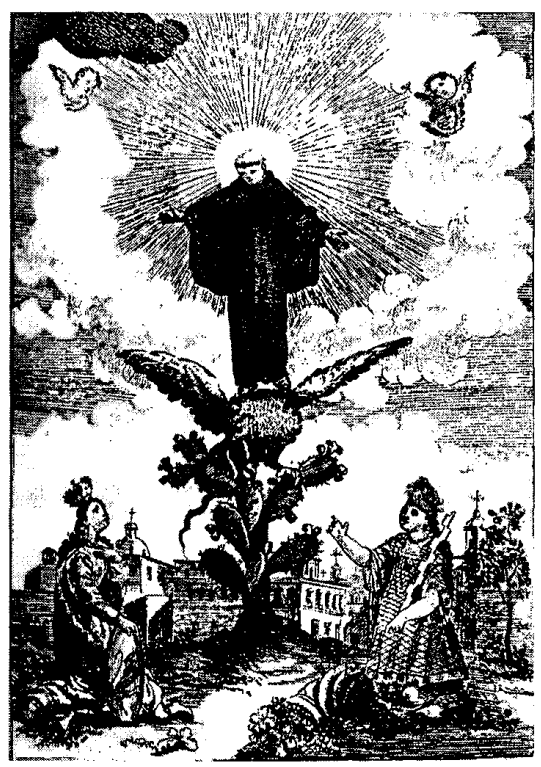

Figura 9. Grabado que celebra el nombramiento de San Felipe de Jesús como patrón de la ciudad de México; dos mujeres a los lados que representan a España y a Nueva España. Fuente: Cuadriello, "Jeroglíficos", 1994, p. 104.

Quizá lo que más sorprende del extraordinario proceso de formación y depuración de símbolos de identidad de esta época es la unión del antiguo emblema mexicano con la imagen de la Virgen de Guadalupe. Este vínculo cobró una fuerza inesperada cuando en 1737 se declaró a la Guadalupana, patrona de la ciudad de México, y más tarde fue elevada al rango de protectora de Nueva España (1746). El papa Benedicto XIV consagró esta predilección por la Virgen morena en 1754 , cuando le confirmó el título de protectora del reino y dispuso que se le dedicara una fiesta litúrgica en el calendario cristiano. Como lo ha mostrado Jaime Cuadrie$110,{ }^{16}$ cada uno de estos acontecimientos fue celebrado con pompa religiosa y júbilo popular, y con una espléndida serie de obras plásticas que muestran la íntima relación que se estableció entre el emblema del águila y el nopal y la Virgen de Guadalupe (fig. 10).

Así, en una notable pintura de José Ribera y Argomanis (1737) se presenta la figura de Juan Diego a la izquier$\mathrm{da}$, ofreciéndole a la Virgen la tilma y unas flores para que se produzca el milagro del estampamiento de la imagen. En el lado derecho un indígena, que representa al reino de Nueva España, pronuncia las palabras canónicas que eran la divisa de la Virgen en ese siglo: Non fecit taliter omni nationi (no hizo nada igual con ninguna otra nación). En la parte inferior el águila posada en el nopal sostiene a la Virgen y los recuadros que describen el momento exultante de la aparición (fig. 11).

Esta serie de pinturas, grabados, retablos y esculturas que desafortunadamente no podemos reproducir aquí, muestra que a fines del siglo XviII la imagen de Guadalupe se había convertido en un símbolo polisémico cuyas diversas representaciones afirmaban la identidad de los nacidos en Nueva España. Era una expresión del reino de Nueva España, la madre intercesora de los indios y la protectora celestial de la

16 Véanse Cuadriello, Maravilla, 1984; "Jeroglíficos", 1994, pp. 91-96, y "Visiones", 1995. 


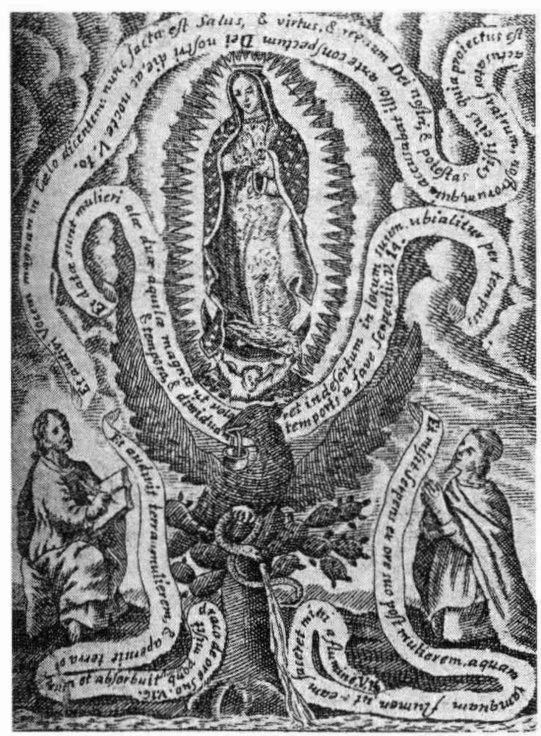

Figura 10. Grabado de Miguel de Villavicencio, siglo XVIII, con la imagen de la Virgen de Guadalupe posada sobre las armas mexicanas. Fuente: Cuadriello, "Visiones", 1995, p. 19.

nueva población mestiza. En las escenas principales de estas obras el virreinato manifiesta su individualidad frente a España, mientras que el despliegue de las armas mexicanas expresa la identidad con el territorio americano.

La imagen de la Virgen de Guadalupe, acompañada con las insignias de la antigua Tenochtitlán, se convirtió así en la representación más genuina del reino de Nueva España: era el símbolo de lo propiamente mexicano; unía el territorio antiguamente ocupado por los mexicas con el sitio milagrosamente se-

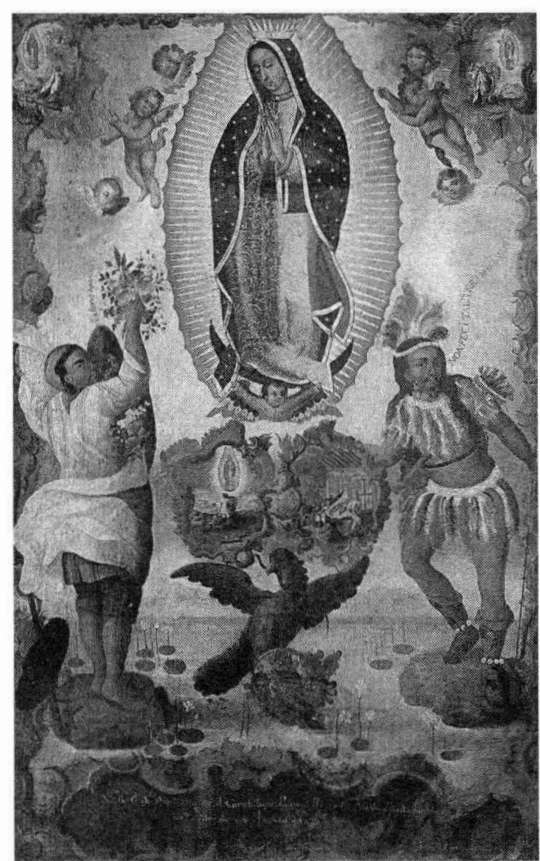

Figura 11. Pintura de José Ribera y Argomanis, 1778, que celebra la designación de la Virgen de Guadalupe como patrona de la ciudad de México. Fuente: Cuadriello, "Visiones", 1995 , p. 34.

ñalado para la aparición de la madre de Dios. En una fórmula inédita, los conceptos de territorialidad, soberanía política, protección divina e identidad colectiva se fundieron en un símbolo religioso que a fines del siglo XVIII era el más venerado por los habitantes de Nueva España. ${ }^{17}$

17 Florescano, Bandera, 1998, cap. II. 
LA GUERRA DE INDEPENDENCIA Y LOS INICIOS DE UN NUEVO PROYECTO NACIONAL

Por la vía de la insurgencia armada, Hidalgo y Morelos proclamaron la independencia de España, reconocieron en el pueblo la fuente original de la soberanía, repudiaron el gobierno del antiguo régimen y delinearon las bases para organizar políticamente a la nación liberada. Primero en los decretos que Hidalgo y Morelos promulgaron durante la insurrección, luego en el Acta de Independencia y en los documentos previos al Congreso de Chilpancingo, y finalmente en los Sentimientos de la Nación y en la Constitución de Apatzingán, los principios constitutivos de la nación (autonomía, soberanía, libre determinación, voluntad popular, igualdad), entraron a formar parte de la memoria colectiva.

Miguel Hidalgo (fig. 12) y José María Morelos se identificaron con las masas que integraban sus ejércitos y asumieron la responsabilidad de actuar en nombre de ellas. Aceptaron ser mandatarios de las demandas populares. Si la revolución, en el momento en que se desencadena, traslada la soberanía a las masas armadas que a partir de ese momento actúan por sí y transforman la realidad, las decisiones que va tomando Hidalgo en la guerra son consecuentes con esa nueva realidad. Como dice Luis Villoro, los "decretos de Hidalgo no hacen sino expresar la soberanía efectiva del pueblo". Desde su alocución del 16 de septiembre de 1810 , la abolición del tributo simboliza la destrucción del derecho existente: "No existen ya para nosotros ni el rey ni los tributos." 18

La abrogación del tributo anuncia una modificación más profunda de la realidad: la destrucción del orden antiguo. Éste es el sentido que tienen las otras decisiones que adopta Hidalgo en representación de las masas.

Revestido por la autoridad que ejerce por aclamación de la nación, Hidalgo abole la distinción de castas y la esclavitud, signos de la infamia y opresión que ejercían las otras clases sobre los negros y mestizos. ${ }^{19}$

En el caso de Morelos (fig. 13), la identificación con las aspiraciones del movimiento popular es aún más genuina:

Morelos empieza su carrera militar como uno de tantos caudillos salidos de las filas del bajo clero. No es ningún "letrado"; pertenece por el contrario a las clases más humildes $[\ldots]$ surgido del pueblo, conviviendo siempre con él, es el representante más auténtico de la conciencia popular. ${ }^{20}$

Presionado por los licenciados y letrados criollos que le exigen definir el proyecto político del movimiento insurgente, Morelos enuncia, con palabras emocionadas y sencillas, un proyecto político centrado en la soberanía popular y la desaparición de las desigualdades que dividían a la población:

18 Villoro, Proceso, 1986, p. 80.

19 lbid.

${ }^{20}$ Ibid., pp. $98-99$ 


\section{SECUENCIA}

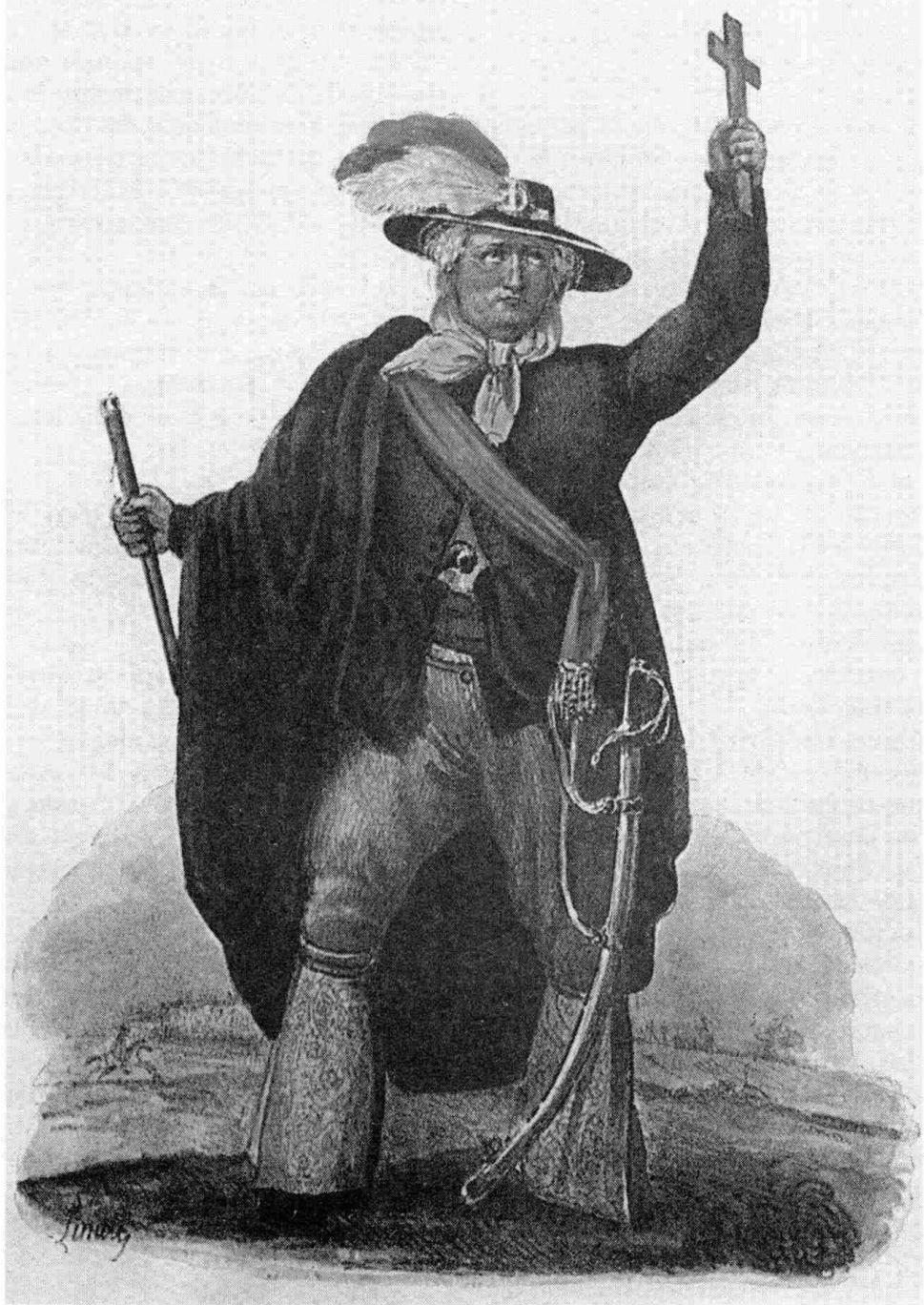

Figura 12. Imagen de Miguel Hidalgo. Fuente: Linati, Trajes, 1956, pl. 16. 
Quiero que tenga [la nación] un gobierno dimanado del pueblo [...] Quiero que hagamos la declaración que no hay otra nobleza que la de la virtud, el saber, el patriotismo y la caridad; que todos somos iguales pues del mismo origen procedemos; que no haya privilegios ni abolengos; que no es racional, ni humano [...] que haya esclavos, pues el color en la cara no cambia el del corazón ni el del pensamiento; que se eduque a los hijos del labrador y del barretero como a los del más rico hacendado; que todo el que se queje con justicia, tenga un tribunal que lo escuche, que lo ampare y lo defienda contra el fuerte y el arbitrario. ${ }^{21}$

Morelos es también un jefe creador de nuevos héroes y símbolos. Es el primero que eleva a los dirigentes indígenas que defendieron sus pueblos ante las tropas de Hernán Cortés al sitial de héroes de la patria. También fue el primero que intentó fundir el culto a los héroes de la antigüedad indígena con el culto a los héroes del movimiento insurgente. En su discurso de apertura del Congreso de Chilpancingo (1813), luego de referirse al país con su nombre antiguo (Anáhuac), invoca los. "Genios de Moctezuma, Cacama, Quautimozin, Xicoténcatl y Caltzontzin", para celebrar con ellos el "fausto momento en que vuestros ilustres hijos se han congregado para vengar vuestros ultrajes y desafueros y librarse de las garras de la tiranía francmasónica que los iba a sorber para siempre". Con este mismo propósito llama a participar en el Congreso de Chilpancingo a los " $¡$ Manes

21 lbid., p. 101. de los muertos de las Cruces, de Aculco, de Guanajuato y de Calderón, de Zitácuaro y de Cuautla, unidos a los de Hidalgo y de Allende!"22

Los datos disponibles indican que fue José María Morelos quien por primera vez colocó el antiguo emblema del águila y el nopal en el medio de una bandera insurgente (fig. 14). En julio de 1815 , en un decreto expedido en $\mathrm{Pu}$ ruarán, Morelos acordó que la bandera nacional debería tener "un tablero de cuadros blanco y azul celeste", los colores de la Virgen María, y "en el centro las armas del gran sello de la nación":

un águila mexicana de frente, con las alas extendidas, mirando hacia su derecha, con una serpiente en el pico, parada sobre un nopal que nace de un lago. Todo esto circundado por un óvalo dorado, rematado con una corona de laurel y una cintilla blanca que dice: Independencia Nacional. ${ }^{23}$

Como se advierte, el movimiento insurgente inaugura un nuevo proyecto histórico y crea simultáneamente sus propios anclajes políticos, sus héroes y símbolos y los cantos que exaltan esa gesta. En el movimiento que encabezaron Hidalgo y Morelos se expresó con fuerza la tradición mítica y religiosa de los grupos indígenas, las demandas sociales de los sectores más desamparados y los ideales de autonomía, patriotismo y fervor guadalupano de los criollos. Este movimiento plural y poderoso que por primera vez fundió

22 Herrejón, Antología, 1985.

${ }^{23}$ La bandera de México, 1985, p. 106; Lemoine, Morelos, 1985, pp. 560-561. 


\section{SECUENCIA}

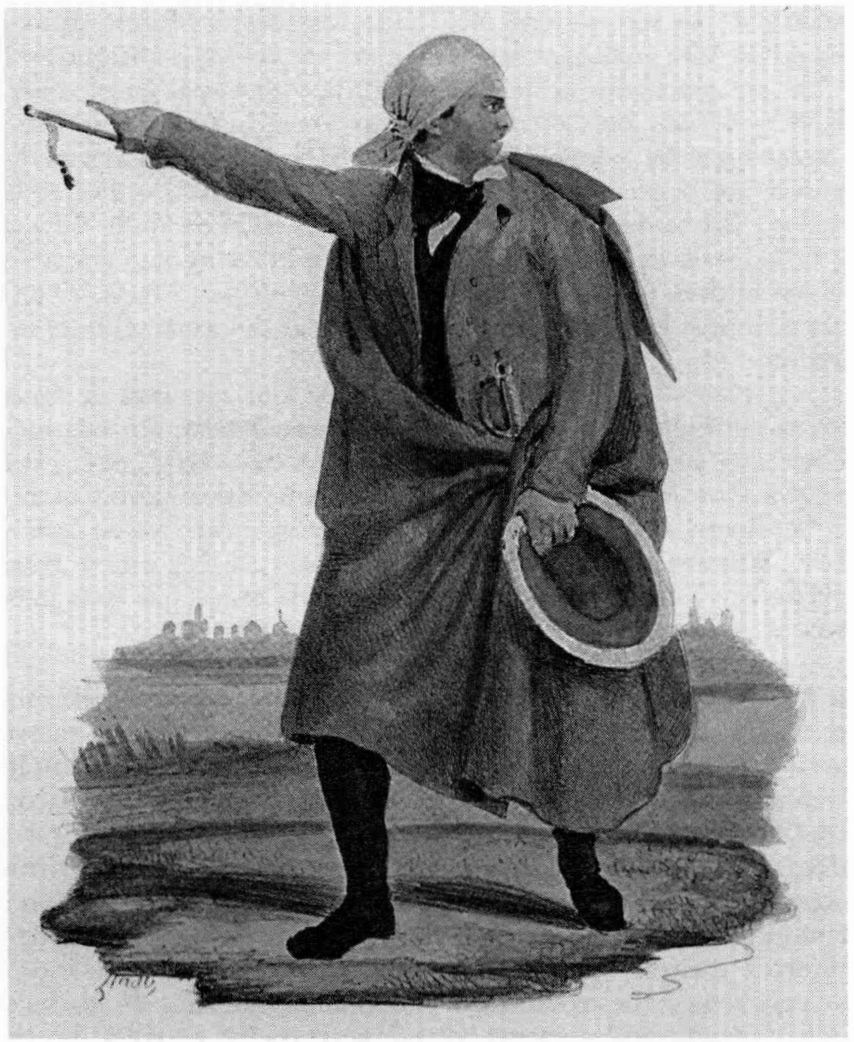

Figura 13. Imagen de Morelos. Fuente: Linati, Trajes, 1956, pl. 46. 


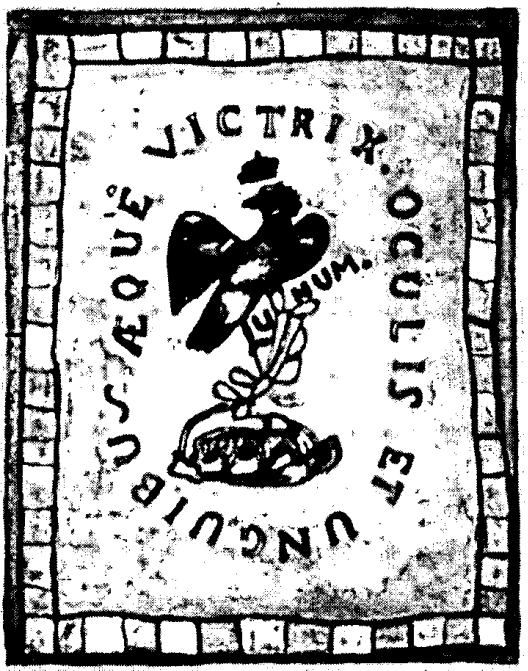

Figura 14. Bandera atribuida a las tropas de Morelos. Museo Nacional de Historia.

las pulsiones de las masas indígenas con las aspiraciones políticas del grupo criollo, encontró en Hidalgo y Morelos su máxima expresión y capacidad de realización. ${ }^{24}$

LOS FUNDADORES DEL NACIONALISMO HISTÓRICO: FRAY SERVANDO TERESA de Mier y Carlos María de BUSTAMANTE

Fray Servando Teresa de Mier escribió en 1813 su Historia de la Revolución de Nueva España para refutar las diatribas contra la insurgencia que hacían correr los realistas españoles y para presentar,

${ }^{24}$ Florescano, Memoria, 1994, pp. 511-514. ante Europa y los propios americanos, un alegato a favor de la independencia.

La primera parte de la Historia de la Revolución de Nueva España relata el derrocamiento del virrey Iturrigaray. La segunda narra con prosa exaltada la insurtección del cura Hidalgo y la cruenta represión desatada contra ella por las fuerzas realistas. Inspirándose en su héroe Bartolomé de las Casas, Mier equiparó esa represión a los salvajes episodios de la conquista. La última parte está formada por el libro XIV, que ocupa un tercio de la obra y es una demostración formidable de las causas que para Mier justificaban la independencia.

Mier no es sólo el primer cronista de la insurgencia y uno de los actores del drama revolucionario que toma la pluma para defender la causa rebelde. Es el creador de una original argumentación histórica y política a favor de la independencia. El argumento central de Mier es que el vínculo que unió a los pueblos de América con los reyes de España se fundaba en un pacto antiguo, escrito en las Leyes de Indias: un "pacto solemne y explícito que celebraron los americanos con los reyes de España [...] y está autenticado en el mismo código de sus leyes. Ésta es nuestra magna carta". 25

Luego de probar la existencia de esa antigua constitución, Mier desarrolló otra idea no menos original, enunciada antes por Francisco de Vitoria: las Américas, decía, no eran colonias, sino verdaderos reinos. Aunque teóricamente formaban parte de Castilla, tenían

25 Teresa de Mier, Historia, 1922, pp. 166-167; un excelente análisis del alegato político de Mier puede verse en Teresa de Mier, Ideario, 1978. 
sus propias instituciones: virrey, Consejo de Indias, Real Audiencia, Universidad, Real Hacienda, etcétera. Quería decir que su situación política era comparable a la de los reinos de Aragón, Portugal y Flandes, "con igual principado soberano, y conservando sus leyes, fueros y pactos". ${ }^{26}$

Sin embargo, Mier argumentó que esa antigua constitución que protegía la libertad y el desarrollo de los americanos fue anulada por el despotismo de la monarquía. Los indios casi fueron exterminados por la avaricia de los españoles y luego sometidos a un tutelaje que los redujo a la condición de infantes perpetuos; los criollos perdieron sus derechos y se les negó toda posibilidad de ascenso social y político; a las castas y los mestizos se les declaró seres de condición infame; los virreyes, las audiencias y las instituciones se tornaron tiránicos; el monopolio comercial absorbió las riquezas americanas; las humanitarias Leyes de Indias se volvieron letra muerta. En una palabra, los antiguos reinos americanos perdieron ese carácter y se convirtieron en auténticas colonias expoliadas por el despotismo. Mier concluía que el despotismo de los reyes españoles había anulado el antiguo pacto social contraído con los americanos, de manera que éstos tenían el derecho de romper el vínculo político que los ataba a la corona.

Más adelante Mier se dedicó a destruir los supuestos títulos en que España hacía descansar su derecho a la dominación de sus posesiones de ultramar.

${ }^{26}$ Ibid., t. II, pp. 197-99; Brading, Orígenes, 1980, p. 72.
El descubrimiento, la conquista y la pacificación de la tierra son títulos nulos en sí mismos porque el descubrimiento se convirtió en explotación, la conquista en masacre y la pacificación en despoblación. Los misioneros que divulgaron el Evangelio en América no ejercitaron esa misión inducidos por España, sino que fueron solicitados por los conquistadores y los mismos americanos, quienes también pagaron con sus recursos la cristianización de los indios y el establecimiento de las instituciones religiosas. La silla apostólica no podía hacer ninguna donación de las tierras americanas por la simple razón de que no tenía sobre ellas ningún título legítimo de propiedad. América no le debía a España la civilización; al contrario, España fue quien más se benefició del contacto con América, pues de las tierras del nuevo mundo salieron las plantas, los cultivos, la fauna, los metales preciosos, los nuevos conocimientos geográficos y el comercio que transformaron a España en una potencia mundial. En lugar de que esas riquezas impulsaran el desarrollo de los americanos, España las utilizó en su beneficio exclusivo y convirtió la relación con América en una servidumbre que se oponía al progreso material y cultural de los americanos.

Arguyó que América no requería nada de España, sino que era ésta quien para sobrevivir necesitaba las riquezas americanas. Fundado en esos razonamientos llega al extremo de afirmar: "nosotros somos la metrópoli. Vosotros sóis lo accesorio de la monarquía, y las Américas lo principal." Concluye entonces que para romper las trabas que frenaban el desarrollo de sus potencialidades, los 
americanos no tenían más alternativa que independizarse de España. ${ }^{27}$

Al observar los peligros que acechaban a las nuevas naciones que optaban por la liberación, Mier hizo un llamado a la unidad de los países americanos para defender su independencia en forma duradera: "Seremos libres, decía, si estamos unidos." Así, por la vía del compromiso político, Servando Teresa de Mier transita del discurso patriótico que no se atrevía a nombrar la palabra independencia, al discurso comprometido a favor de la liberación plena de su patria. Al igual que otros sacerdotes y letrados criollos, Mier participó en la lucha por la independencia como insurgente y panfletista; pero él fue el primero que tradujo esas experiencias en un discurso que demostraba la razón histórica que asistía a su patria para liberarse de la sujeción española. A diferencia de los patriotas criollos que le precedieron y que se limitaron a rescatar los símbolos históricos que no creaban un conflicto con la herencia colonial, Mier elaboró su Historia aceptando la contradicción entre el proyecto independiente de los insurgentes y el proyecto español de conservar a Nueva España sujeta a la metrópoli.

Éste es el parteaguas político que separa a la Historia de Mier de las reconstrucciones del pasado hechas antes por los criollos. Desde el momento en que Mier lucha por crear una nación independiente, su lectura del pasado adquiere un sentido opuesto a las interpretaciones anteriores. Bajo este en-

27 Teresa de Mier, Historia, 1922, t. II, pp. 314-318. foque, la epopeya de la conquista y la celebrada historia de las instituciones y del gobierno peninsular se convirtieron en crónica de la destrucción de las Indias.

La insólita interpretación del pasado que Mier plasmó en su Historia produjo un doble efecto. Por un lado su virulenta crítica de la conquista y del dominio español transformó los tres siglos del virreinato en la época negra de la historia mexicana. La Historia de la Revolución de Nueva España es la primera obra que pone en jaque las imágenes de la conquista elaboradas por los cronistas españoles, la primera crónica de la insurrección de Hidalgo y un surtidor de argumentos, metáforas e imágenes antiespañolas.

Las interpretaciones que más tarde revisaron críticamente el pasado colonial abrevaron en la cantera abierta por Mier. Su obra remata el difícil proceso que para los americanos significó romper con las ataduras políticas y mentales que los unían con España. Como se recordará, la abdicación de Carlos IV a favor de José Bonaparte dio pie a los criollos del Ayuntamiento de la ciudad de México para declarar que mientras durara la usurpación, Nueva España reasumía su soberanía para determinar por sí su destino, pero sin romper sus vínculos con Fernando VII. Más tarde Hidalgo y Morelos encabezaron la lucha por la independencia y le dieron cauce a las reivindicaciones de las masas populares pero sin recusar por completo al monarca español.

Mier es el último eslabón de esa serie de rompimientos liberadores. Su Historia es una impugnación total de la dominación española. Esta negación del 
pasado colonial inicia, como lo señaló hace tiempo Luis Villoro, la segunda etapa ideológica de la insurgencia. El rechazo del vínculo que unía a Nueva España con su dominador y el grito de independencia de Hidalgo son los episodios clave de la primera fase de ese proceso. La segunda comienza con el enjuiciamiento del régimen colonial y culmina con el repudio del virreinato, que es precisamente la conclusión que se lee en la Historia de Servando Teresa de Mier. ${ }^{28}$

Mier impugnó los proyectos monárquicos e imperiales que entonces hicieron su aparición y fue un portavoz de los valores republicanos, un convencido del ejercicio irrevocable de los derechos ciudadanos y un creyente en las virtudes de la vida democrática. Al contrario de sus opositores liberales, pensaba que esos valores exigían tiempo y formas institucionales adecuadas para convertirse en prácticas efectivas de la población, que en su mayoría, decía, era una masa ignorante, sin capacidad para reflexionar sobre los graves problemas que desafiaban a la nación. Sus enemigos fueron el despotismo, el militarismo y el oscurantismo religioso. Envolvió ese ideario político con un nacionalismo emotivo que recogía tradiciones y memorias históricas compartidas por extensos sectores de la población. La Virgen de Guadalupe, la identidad de Quetzalcóatl con Santo Tomás, la leyenda negra de la dominación española, la lucha heroica de Hidalgo y de los primeros insurgentes y el mito de la nación indígena liberada

28 Villoro, Proceso, 1981, pp. 150-152 y 153165. por la declaración de independencia, vinieron a ser, gracias a las obras de Mier, fundamentos de la nueva memoria de la nación. ${ }^{29}$

Carlos María de Bustamante, un licenciado católico y patriota, le dio otra proyección al sentimiento nacionalista que brotó de la insurgencia y que Mier fue uno de los primeros en plasmar en libros. Bustamante nació en Oaxaca en 1774, y en 1794 se trasladó a la ciudad de México, donde entró en contacto con las ideas ilustradas y los cambios mentales que introdujeron los gobernantes Borbones. En 1799 viajó a Guanajuato y conoció a Miguel Hidalgo, de quien más tarde, al evocar ese encuentro, haría una semblanza anticipadamente revolucionaria.

Bustamante se dio a conocer en la vida pública como periodista, una vocación que conservó hasta sus últimos días. En 1805 fundó, con Jacobo de Villaurrutia, el Diario de México. En esa actividad y ya plenamente identificado con el grupo de letrados criollos cercano al virrey Iturrigaray, lo sorprendió el golpe de Estado que los comerciantes dirigieron contra el virrey. Pudo escapar a la cárcel que destruyó a sus compañeros, se integró al grupo clandestino de "Los Guadalupes" y comenzó a colaborar en forma anónima en la prensa insurgente promovida por la Junta de Zitácuaro.

En 1813 llegó a Chilpancingo, conoció a Morelos y participó como diputado en el "Congreso de Anáhuac", que él bautizó con ese nombre. A par-

29 Además de los estudios sobre Mier de Villoro, O'Gorman y Brading, véase la excelente novela de Arenas sobre fray Servando, Mundo, 1978. 
tir de entonces se involucró con el movimiento rebelde, se volvió un devoto de Morelos, abrazó el partido del movimiento popular y se distanció de los licenciados ilustrados que anteponían la soberanía del Congreso a la soberanía popular. Bustamante ligó su suerte con la de Morelos desde 1813 hasta la muerte del jefe sureño. 30

A Bustamante debemos dos obras por las cuales su nombre permanecerá grabado en el libro de los fundadores de la memoria nacional. La más conocida es su Cuadro histórico de la Revolución mexicana, que comenzó a publicar en 1821 y concluyó en 1827.31 Es una obra escrita en forma de cartas, que se iban publicando conforme el autor las entregaba a la imprenta y que más tarde fueron reunidas en cinco volúmenes que sumaron casi dos mil páginas. Se trata de una acumulación de documentos mezclada con comentarios desordenados del propio Bustamante, difícil de entender por la anarquía de los asuntos tratados y la intromisión de anécdotas y asuntos triviales. ${ }^{32}$

30 Lemoine, Carlos, 1984, pp. IX-X. Otros datos biográficos de Bustamante se encuentran en el estudio preliminar que hizo Ernesto Lemoine para la edición de la $A$ beja de Chilpancingo; véase también Castelán, Fuerza, 1997.

${ }^{31}$ La obra lleva el título de Cuadro bistórico de la revolución de la América Mexicana, comenzada el quince de septiembre de mil ochocientos diez por el ciudadano Miguel Hidalgo y Costilla, dedicada al ciudadano José María Morelos. La segunda edición, corregida y aumentada por el autor, se publicó en 1843-1846. Véase Lemoine, Carlos, 1984, p. XII.

32 Ibid., p. XIV, y Ortega y Medina, "El historiador don Carlos María de Bustamante ante la conciencia histórica mexicana".
La segunda gran obra de Bustamante es el Diario histórico de México, un torrente de páginas manuscritas que suma 42 volúmenes. El Diario exhibe las mismas deficiencias que se le achacan al Cuadro bistórico: aglomeración desordenada de documentos, falta de rigor en la selección y presentación de los textos, comentarios innecesarios, mezcla de hechos sustantivos con anécdotas triviales, garrulería patriotera, etc. Pero a pesar de esas deficiencias, el Cuadro y el Diario integraron el primer corpus documental de la insurgencia, la primera memoria escrita del acontecimiento que cambió la vida de los mexicanos y definió un nuevo rumbo para la nación.

Las obras de Bustamante contienen un mensaje que las hizo perdurables y que se impuso a las propias limitaciones del autor. En primer lugar el Cuadro bistórico y el Diario son narraciones que exaltan la insurrección popular encabezada por Hidalgo, Morelos y los patriotas de la primera hora. El movimiento popular iniciado en la madrugada del 16 de septiembre de 1810 y sus caudillos son los héroes de los relatos de Bustamante. Las masas populares, los hombres humildes y anónimos convertidos en llama revolucionaria, y los dirigentes que abanderaron la causa popular, son los héroes que merecen las loas más emotivas del cronista.

Con esos héroes y la narración de sus batallas, triunfos y derrotas, Bustamante construyó un panteón patriótico, un mapa heroico y una crónica emotiva de la independencia. Las obras de Bustamante prolongan las ideas indigenistas caras a Servando Teresa de Mier. Exaltan la antigüedad azteca y difunden la tesis de la nación indígena esclavizada 
por los españoles y luego liberada por los insurgentes, que de esta manera vienen a ser los herederos de Cuauhtémoc. De muchas páginas del Cuadro y del Diario brota la imagen de una continuidad histórica entre el imperio idealizado de los aztecas y la nación independiente liberada por los insurgentes. A Bustamante, sobre todo, se debe el neoaztequismo que proliferô durante la guerra y en los años que siguieron a la declaración de independencia. Por iniciativa de Bustamante el Congreso de Chilpancingo recibió el nombre de Congreso de Anábuac. La obsesión por restaurar la nación indígena impulsó a Mier y a Bustamante a proponer, sin éxito, que la nueva república llevara el nombre de Anábuac.

Movidos por esos resortes solicitaron ante el Congreso cambiar la bandera trigarante del Plan de Iguala por la que llevaba los colores del reino de Motecuhzoma. En varias de sus obras Bustamante convierte a los antiguos reyes indígenas en manes, en sombras protectoras de los héroes de la independencia. Compone galerías de los antiguos reyes indígenas y las ofrece como espejo de virtudes del gobernante, y a través de esas idealizaciones transforma el México antiguo en una edad augusta. El afán por darle a la nación liberada una imagen prestigiosa de su pasado llevó a Bustamante a escribir sus Mañanas de la Alameda (1835), una obra animada por el deseo de

instruir al pueblo en lo que más le importa saber, que es la bistoria antigua de su país, para que lo aprecie dignamente y procure imitar las acciones heroicas de nuestros ma- yores, cuya memoria pretendió sepultar el gobierno español. ${ }^{33}$

Estos propagandistas de las glorias del México antiguo fueron también los fundadores de una nueva mitología histórica, los creadores de un panteón de héroes, los iniciadores del nuevo culto cívico y los difusores de una retórica nacionalista destinada a perdurar. Más que Mier, Bustamante fue un creador compulsivo de mitos, héroes, ceremonias y símbolos nacionalistas, inspirados en su patriotismo y en su indigenismo histórico. Recogió los viejos mitos criollos y logró incorporarlos en el ritual cívico de la nación republicana. Como buen criollo, fue un guadalupano ferviente y en varias ocasiones encontró tiempo para publicar escritos sobre la aparición guadalupana en los que defendió la autenticidad del milagro y la identidad de Quetzalcóatl con el apóstol Santo Tomás.

Es casi seguro que él haya sugerido a Morelos declarar fiesta nacional el 12 de diciembre, de modo que ese día la nación entera se volcara a celebrar a la "Patrona de México". De él y de Mier vino la propuesta, aprobada luego por el Congreso, de celebrar el 16 de septiembre como día de la independencia nacional. Esa compulsión conmemorativa llevó a Bustamante a proponer el primer monumento dedicado a honrar la memoria de los héroes de la independencia: imaginó la construcción, en la plaza mayor de la capital, de cuatro columnas dedicadas a Hidalgo, Morelos, Allende y Mina. También propuso

${ }^{33}$ Bustamante, Mañanas, 1835. 
levantar, en la plaza de Santo Domingo, una columna que celebrara la independencia, y que en uno de sus pedestales se honrase la memoria de Iturbide. En el Cuadro bistórico, en el Diario y en sus numerosos libros y publicaciones periodísticas estableció el modelo de los panegíricos, celebraciones, aniversarios y monumentos que más tarde habrían de recordar las hazañas de los héroes de la patria y celebrar los actos fundadores de la nación. ${ }^{34}$

Desde los años iniciales de la insurgencia Bustamante intuyó la necesidad de crear los símbolos, héroes y cultos del movimiento revolucionario, y se asignó a sí mismo la misión de ser el primer surtidor de imágenes nacionalistas. A la lista de héroes de la insurgencia cuyos perfiles patrióticos él más que nadie contribuyó a difundir (Morelos, Hidalgo, Allende, Aldama), agregó los nombres míticos de Quetzalcóatl, Netzahualcóyotl, Motecuhzoma, Cuauhtémoc y muchos más, con los cuales compuso un panteón entreverado de héroes indígenas e insurgentes que fortalecía su tesis acerca de la continuidad entre la nación indígena y la república. Bustamante fue también uno de los propagadores más eficaces de la inflamada retórica nacionalista que se volvió común en los festejos patrióticos de la nación independiente: una retórica que olvidó explicar el hecho que exaltaba para concentrarse en la pura fuerza emocional de su decla-

${ }^{34}$ Sobre el nacionalismo histórico de Bustamante, véase Vázquez, Nacionalismo, 1970, pp. 32-33; Brading, Orígenes, 1980, pp. 118-19; Castelán, Fuerza, 1997, pp. 127-134. ración, en la intensidad evocativa de su mensaje y en el efecto sentimental que éste provocaba en sus oyentes. ${ }^{35}$

Bustamante fue también un precursor en la tarea que más tarde ocupó el esfuerzo de varias generaciones de eruditos: el rescate y la edición de las obras de los misioneros y otros autores laicos no publicadas por el gobierno español. Los mismos libros que leía sobre el México antiguo y su acceso a los archivos le revelaron la existencia de un número considerable de textos inéditos, y desde entonces y hasta su muerte comprometió sus escasos recursos para publicarlos, a tal punto que se convirtió en el mayor editor de obras históricas de su época.

Desde los años en que era editor del Diario de México (1805-1812), inició la publicación de los manuscritos del historiador indígena Chimalpahin. En 1821 dio a las prensas una Galería de antiguos principes mexicanos dedicada a la suprema potestad nacional que les sucediere en el mando para su mejor gobierno, a la que siguieron la Crónica mexicana, de Alvarado Tezozómoc; la Historia de la conquista de México, de Francisco López de Gómara; una monografía de Tezcoco, de Mariano Veytia, y la primera edición de la monumental Historia general de las cosas de la Nueva España, de Bernardino de Sahagún. Además, Bustamante editó obras valiosas sobre el virreinato, como la crónica de los tres siglos del gobierno èspañol del padre Andrés Cavo, la Historia de la Compañia de Jesús, de Francisco Javier Alegre,

35 Vázquez, Nacionalismo, 1970, pp. 32-33, y Brading, Origenes, 1980, pp. 118-19. 
y las Enfermedades políticas, de Hipólito de Villarroel. ${ }^{36}$

Editor inescrupuloso, Bustamante alteró los títulos de las obras que publicó, mutiló o expurgó su contenido y agregó prólogos, notas, documentos ajenos y elucubraciones propias que afectaron el fondo y la forma de los textos originales. Su compulsión editorial poco tenía que ver con la idea de difundir textos valiosos por sí mismos. Cuando Bustamante publica las obras de Sahagún, Chimalpahin, Veytia o Alvarado Tezozómoc, el fin que persigue es combatir los anatemas que vertían los españoles contra la antigua civilización indígena y mostrar, por boca de los frailes y de los eruditos criollos, el desarrollo cultural alcanzado por esos pueblos. Para él los textos sobre los antiguos mexicanos eran una suerte de argumento de autoridad contra las tesis hispanistas que se ensañaban en devaluar ese pasado. Lo mismo ocurre con las crónicas sobre el virreinato, que Bustamante publica porque describen los males prevalecientes en la colonia, o porque justifican la obra civilizadora de los jesuitas, que era la orden que más admiraba y anhelaba restablecer.

Por el procedimiento de editar y comentar los textos prohibidos por las autoridades virreinales, Bustamante inició el proceso de mexicanizar las crónicas elaboradas por los conquistadores, introduciendo en ellas el punto de vista del conquistado, la mirada que al leerlos con los ojos de quien había dejado de ser el sujeto pasivo de la historia, des-

36 Una lista de las publicaciones y ediciones de Bustamante se encuentra en O'Gorman, Guía, 1967. cubrió en ellas voces y contenidos que expresaban un significado diferente al que les habían dado los editores españoles. Al igual que el legado de Mier, el de Bustamante es una obra profundamente política asentada en razonamientos históricos. De esta mezcla entre las demandas políticas de la insurgencia y la compulsión de identificarse con el pasado remoto surgió el singular nacionalismo histórico mexicano.

\section{CONSUMACIÓN Y CELEBRACIÓN DE LA INDEPENDENCIA}

El 27 de septiembre de 1821, fecha de la entrada triunfal del Ejército Trigarante en la capital del país, y el 28 de septiembre del mismo año, fecha de la instalación de la Soberana Junta Provisional Gubernativa y de la Regencia del Imperio, celebraron el arribo a la capital del país del héroe libertador, la instalación de los órganos de gobierno de la nación independiente y la consumación de la independencia.

Después de diez años de guerra, la entrada de Iturbide y del Ejército Trigarante a la ciudad de México vino a ser la primera celebración colectiva y una fiesta popular (fig. 15). Estos actos y la proclamación formal de la independencia fijaron un modelo al que se ajustaron los posteriores festejos conmemorativos. Nació entonces una forma de recordación histórica y un calendario cívico popular que se habría de consolidar en los años siguientes.

El 28 de septiembre el Ejército Trigarante recorrió las principales calles de la ciudad, encabezado por el general Agustín de Iturbide (fig. 16). En la 


\section{SECUENCIA}

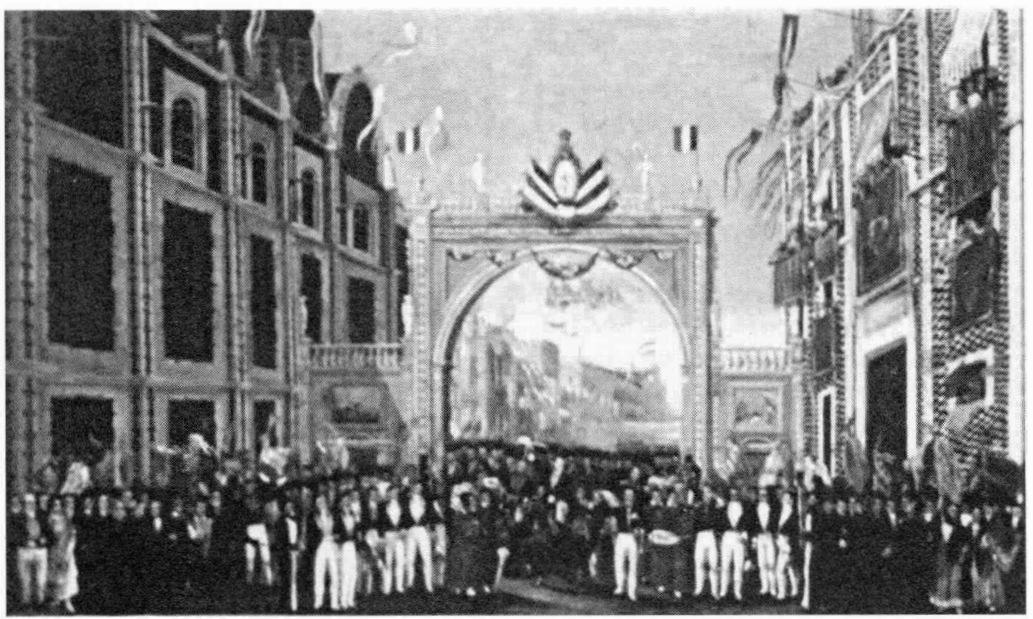

Figura 15. Entrada victoriosa de Iturbide y el Ejército Trigarante a la ciudad de México. Fuente: Jiménez Codinach, México, 1997, pp. 256-257.

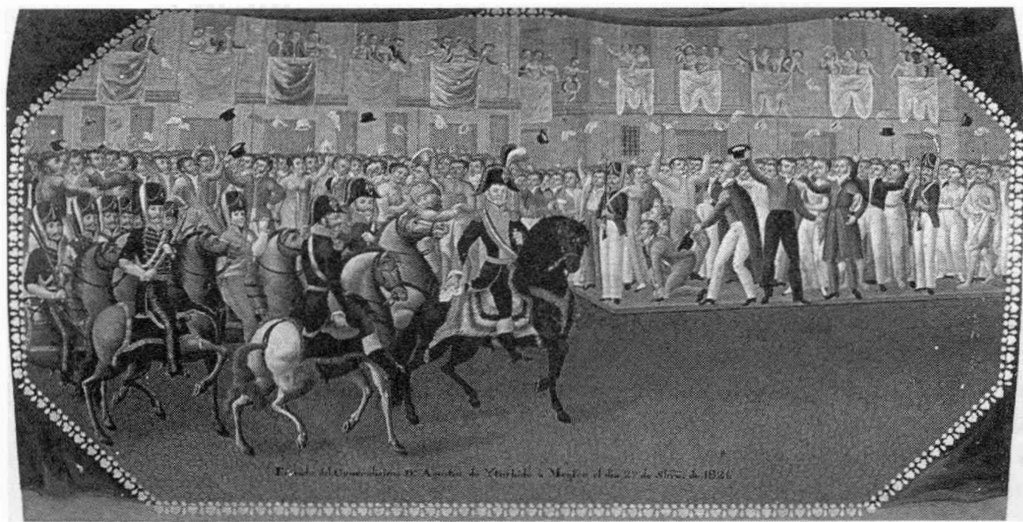

Figura 16. Paseo triunfal del Ejército Trigarante por la ciudad de México. Fuente: Pasado, 1993, p. 52. 
vanguardia iban "las parcialidades de indios, los principales títulos de castilla, y crecidísimo número de vecinos de México". En distintos momentos del recorrido las autoridades de la ciudad y la población le rindieron honores a los libertadores. Cerca del convento de San Francisco, la avanzada del ejército fue recibida por el Ayuntamiento con arco triunfal y la entrega a Iturbide de las llaves de la ciudad, en réplica de oro. La marcha continuó, acompañada por

los más enérgicos y más expresivos vivas del pueblo inmenso que llenaba las calles, los balcones y azoteas, formando el cuadro más animado y sublime que pudo ver México en sus pasados anales. ${ }^{37}$

En toda la inmensa distancia que media entre el palacio y la garita de Belén -dice la Gaceta Imperial-, no se oyeron otras expresiones que las de viva el padre de la patria, el libertador de Nueva España [...], el genio tutelar que nos atrajo el mayor de los bienes [...] El segundo objeto de la admiración de las gentes fue el Ejército Trigarante, compuesto por 8000 hombres de infantería y 10000 caballos...38

Carlos María de Bustamante, el cronista que narró la gesta independiente, relata el traslado a la catedral de los principales jefes del ejército, los miembros del Ayuntamiento, los representantes indígenas de las parcialidades y los títulos de Castilla. En la iglesia, dice, "se entonó el himno Te-Deum por el señor arzobispo, y duró hasta cerca de las

37 Ocampo, Ideas, 1969, p. 16.

38 Ibid. tres de la tarde, sin que cesaran en todo el día las salvas de artillería ni los repiques de las campanas". Al concluir este acto la comitiva volvió a palacio, donde el Ayuntamiento ofreció "mesa y refresco, a que asistieron las principales personas de México, y lo mismo al paseo de por la tarde". 39

Al otro día se constituyó la Junta Provisional Gubernativa y se declaró la independencia, en el salón de acuerdos del palacio nacional. Luego los miembros de la Junta "se dirigieron a la iglesia catedral, donde cada uno, poniendo la mano sobre los Evangelios, juró cumplir fielmente el Plan de Iguala y los Tratados de Córdoba". Por la noche, la Junta dio a conocer el Acta de Independencia, que en sus partes fundamentales, declaraba:

La nación mexicana, que por 300 años ni ha tenido voluntad propia, ni libre uso de la voz, sale hoy de la opresión en que ha vivido.

Los heroicos esfuerzos de sus hijos han sido coronados, y está consumada la empresa eternamente memorable, que un genio superior a toda admiración y elogio [...] llevó al cabo arrollando obstáculos casi insuperables.

Restituida, pues, esta parte del septentrión al ejercicio de cuantos derechos le concedió el Autor de la naturaleza [...] en libertad de constituirse del modo que más convenga a su felicidad [...] declara solemnemente por medio de la junta suprema del imperio, que es nación soberana $e$ independiente de la antigua España. ${ }^{40}$

39 Bustamante, Cuadro bistórico, cap. v, pp. 328-329.

40 Ibid., cap. v, p. 333. 
Estos actos consecutivos: la entrada del Ejército Trigarante a la capital, la instalación de la Junta Gubernativa, el pronunciamiento del Acta de Independencia y el nombramiento de la Regencia del Imperio, le dieron un estatuto legal a la nación independiente. Mediante el festejo jubiloso se hizo pública la separación política de España y su celebración en los pueblos y rincones más alejados dio a conocer la buena nueva a los diferentes sectores sociales.

Quizá el rasgo más significativo de esta celebración es que en el mismo año en que fue festejada en la capital del país se expandió al resto del territorio. En su estudio sobre los actos que saludaron la independencia, Javier Ocampo mostró que su celebración abarcó el conjunto del país y asumió el mismo carácter colectivo, festivo y optimista que en la capital. ${ }^{41}$

41 Véase Ocampo, Ideas, 1969. Otra fuente, Riva Palacio, México, 1884-1889, vol. IV, pp. 18 y 24 dice: "Mientras en la capital del nuevo imperio se verificaban [...las celebraciones de la independencia], las provincias, que ya estaban preparadas para la independencia, la sellaron con las más expresivas manifestaciones de júbilo al recibir la noticia de la entrada del Ejército Trigarante a la ciudad de México." Y en otra parte, añade: "no obstante haberse proclamado y jurado la independencia en casi todas las ciudades y pueblos del imperio de una manera solemne, no se había hecho lo mismo en la capital, y por tanto, la Regencia decretó que tal acto se verificase así en la ciudad de México como en los lugares donde no se había prestado el juramento". Otro testimonio (Ocampo, Ideas, 1969 , p. 39) señala que el número de gentes que presenciaron el juramento de la independencia en la plaza mayor de México fue de 60000 .

\section{LOS NUEVOS RITOS Y CALENDARIOS} DE LA NACIÓN

El antecedente de la fiesta colectiva en México era la conmemoración religiosa. El primer festejo de la nación independiente recoge las formas y lo símbolos de la celebración religiosa, pero les otorga un nuevo sentido y busca definir otros actores, espacios, tiempos y símbolos.

Los actores de la nueva ceremonia cívica son el héroe libertador, el Ejército Trigarante y la nación independiente. Iturbide y su ejército ocupan los principales espacios de las ceremonias, son el centro de la aclamación en las calles y plazas públicas y los más representados en los carros alegóricos, arcos triunfales, pinturas y escenas que muestran en forma realista o simbólica la liberación de la nación. En casi todos los escenarios se representa a la nación bajo la figura de una joven indígena que es liberada de sus cadenas por Iturbide, o es conducida por el héroe a ocupar el sitial más alto.

Los antiguos recintos, planeados para celebrar otras ceremonias y héroes, se transforman y le dan cabida al nuevo culto nacional. Un ejemplo de estas transformaciones es el de la plaza mayor de la capital, en cuya parte central se levantaba la estatua ecuestre de Carlos IV. El 27 de octubre, con motivo de la jura de la Independencia, este lugar sufrió la siguiente modificación física y simbólica (fig. 17):

En la bella plaza mayor y dentro de la elipse en que se halla colocada la estatua ecuestre colosal de bronce del señor Car- 


\section{SECUENCIA}

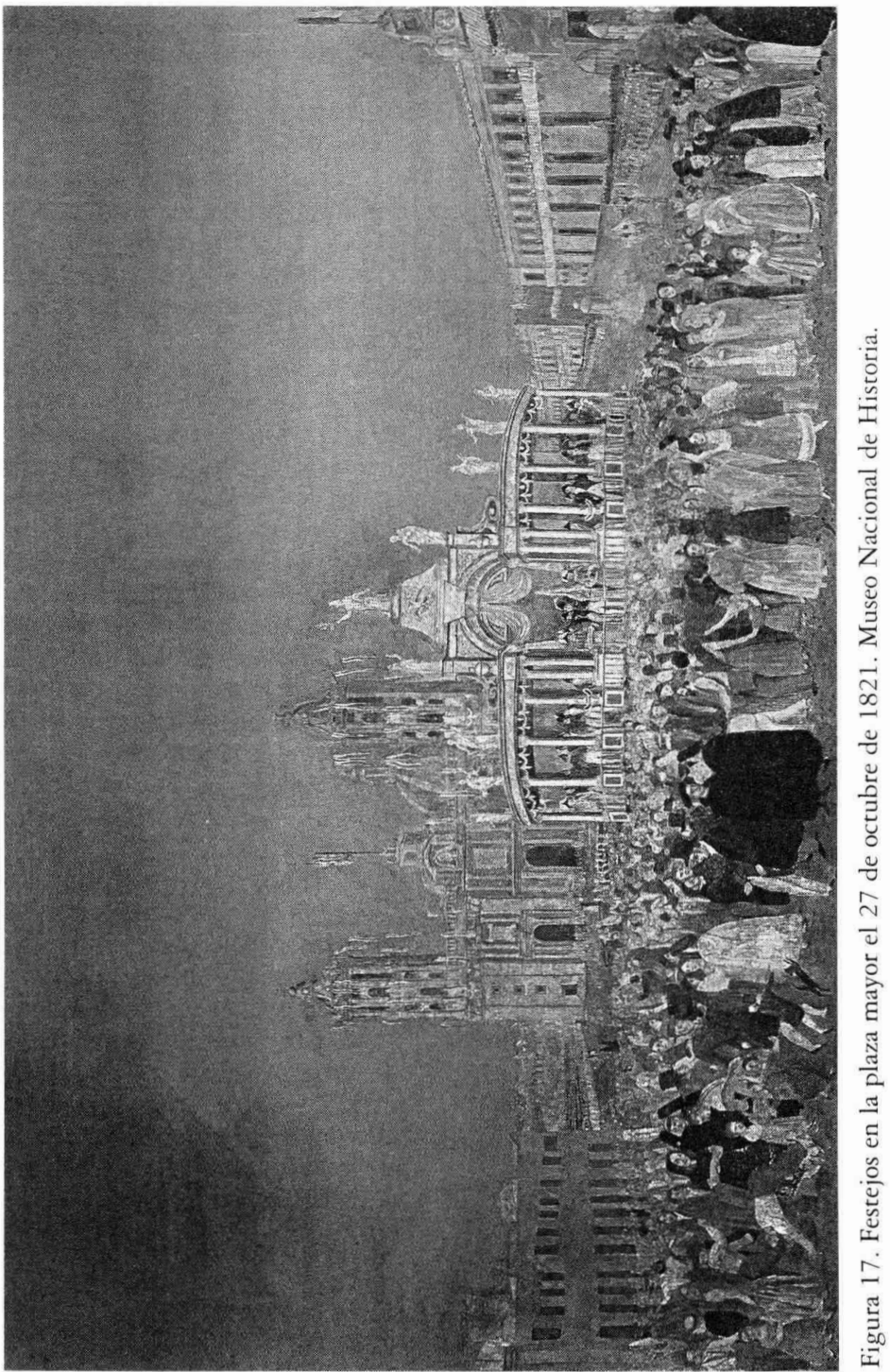


los IV, levantaron un templete de figura rotonda $[. .$.$] en el remate del templete$ [...] se miraba sobre un nopal parada, un águila, la que simbolizaba la libertad de la nación. Los lienzos que cubrían el pedestal representaban, el primero, la elevación de la América septentrional al rango de nación independiente y libre [...] la América representada con todos sus símbolos y vestida del manto soberano, sube por las gradas conducida por su digno hijo el grande Iturbide [...]; al otro lado se miran los fuertes generales del Ejército Trigarante con el plumaje y banda tricolor $[. .$.$] en las gradas del trono$ está un genio con carcaj, arco y macana, que son las armas antiguas con que peleaban los mexicanos...42

Como se advierte, estos actos muestran el entrelazamiento de tradiciones antiguas con concepciones políticas modernas. En la capital, las ciudades del interior $y$ aun en las aldeas se multiplican los proyectos para erigir estatuas, columnas, altares de la patria, pirámides, obeliscos y otros monumentos dedicados a honrar la independencia y sus héroes. ${ }^{43}$

Como ocurre con otros movimientos políticos, en la insurgencia mexi-

\footnotetext{
42 Riva Palacio, México, 1884-1889, vol. Iv, p. 24; Ocampo, Ideas, 1969, pp. 15-16.

43 Un ejemplo de estos proyectos es el siguiente. Un autor propone demoler el mercado del Parián para que la plaza mayor de México quede despejada. "En el centro de esta gran plaza se levantaría una magnífica pirámide con la estatua del libertador del imperio mexicano." Ocampo, Ideas, 1969, p. 101.
}

cana el manejo del tiempo y la fijación del calendario revolucionario son actos imperativos: no admiten más fechas y conmemoraciones que las que dicta el movimiento triunfador. ${ }^{44}$ Por esa razón la fecha de la consumación de la independencia por Iturbide es asumida como la definitoria del proceso insurgente y como el momento fundador de la nación.

Los independentistas de 1821 proclamaron el 27 de septiembre de 1821 el día del nacimiento de la nación y borraron el 16 de septiembre de 1810 , así como las efemérides que los primeros insurgentes habían proclamado momentos gloriosos de la gesta revolucionaria. Estas últimas fueron caracterizadas como fases negativas: momentos en que impera la guerra cruel, la violencia, la anarquía, el saqueo, la destrucción y la contienda civil. A esas fases destructivas se opone la bondad del movimiento de Iturbide, dirigido por los principios de conciliación y unidad, que culminaron en una revolución sin efusión de sangre. ${ }^{45}$

La revolución triunfante olvida sus orígenes violentos y memorializa el momento de la revolución incruenta, unificadora y abierta al futuro. Utiliza la celebración para propagar su versión del acontecimiento revolucionario $y$ difundirlo en los distintos sectores de la población. El nuevo calendario proclama el fin de la revolución y el comienzo de una era fraterna, optimista.

44 Sobre el uso del tiempo y el calendario por el acontecimiento revolucionario, véase Ozouf, Fête, 1976, cap. viII.

45 Ocampo, Ideas, 1969 , pp. 157-160. 
LOS SÍMBOLOS DE LA NACí́N LIBERADA

La fiesta revolucionaria produce también nuevos símbolos e imágenes visuales. Hidalgo y Morelos eran curas y le dieron a sus ejércitos símbolos religiosos como estandartes. Iturbide, en cambio, formado en el ejército realista que combatió a los primeros insurgentes, se vale de símbolos militares para difundir sus programas libertarios. Como se ha visto, convierte la parada militar en centro de la admiración pública y en celebración colectiva. Promueve también, como primer jefe del ejército y cabeza del imperio, la parafernalia de las insignias, los uniformes, las galas, el ceremonial, el boato y la ostentación que en adelante caracterizarán a la persona y a la corte del caudillo militar.

A Iturbide se debe también la institucionalización de uno de los primeros símbolos nacionales: la bandera. El Plan de Iguala que proclamó en 1821 descansaba en tres principios:

la conservación de la religión católica, apostólica, romana, sin tolerancia de otra alguna; la independencia bajo la forma de gobierno monárquico moderado, y la unión entre americanos y europeos. Éstas eran las tres garantías, de donde tomó el nombre el ejército que sostenía aquel plan, y a esto aluden los tres colores de la bandera que se adoptó (fig. 18). 46

El color blanco simbolizaba la pureza de la religión, el encarnado la unión de americanos y españoles y el verde la independencia.

${ }^{46}$ La bandera de Mexico, 1985, p. 106.
Cuando se derrumbó el imperio de Iturbide el Congreso adoptó la república federal como forma de gobierno y transformó los antiguos emblemas de la patria en emblemas de la nación. En la Constitución federal de 1824 se ve el águila, combatiendo con la serpiente, sin corona, parada sobre el nopal heráldico que brota del montículo que emerge de la laguna (fig. 19). La república mantuvo la bandera tricolor del Ejército Trigarante y esta bandera se convirtió en el símbolo representativo de la nación independiente. Era la imagen visual que en los actos públicos identificaba a la patria liberada y expresaba los sentimientos de unidad e identidad nacionales. Fue el primer emblema cívico, no religioso, que unió a la antigua insignia de los mexicas con los principios y las banderas surgidas de la guerra de liberación nacional.

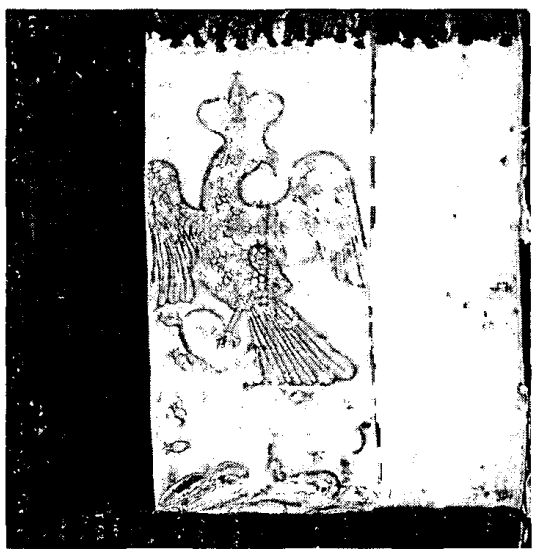

Figura 18. Bandera del imperio de Iturbide, 1822-1823. Fuente: Jiménez Codinach, México, 1997, p. 247. 


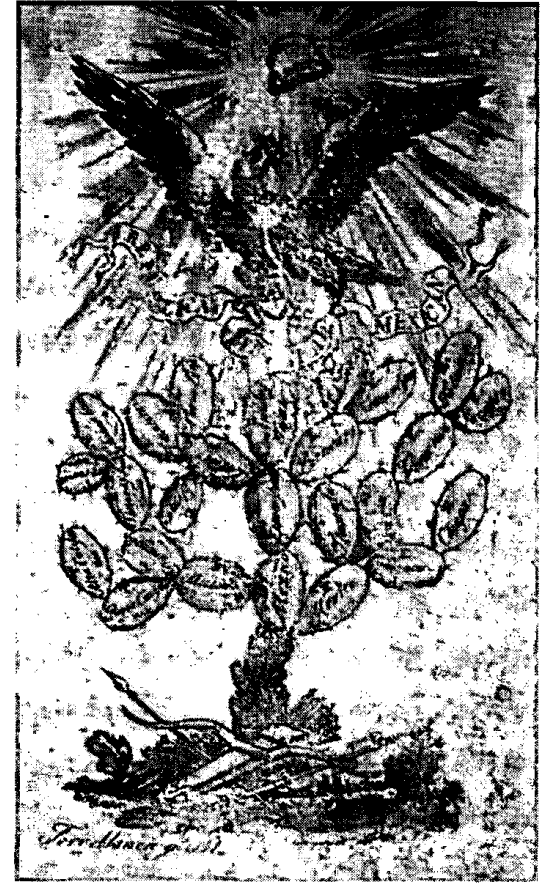

Figura 19. Escudo de la República Federal Mexicana de 1824. Fuente: Rodríguez, México, 1994, p. 141.

Los sentimientos patrióticos tradicionales (la idea de compartir un mismo territorio, lengua, religión y pasado), se integraron al proyecto moderno de constituir una nación soberana dedicada a la persecución del bien común. Así, apoyada en la insurgencia armada y en el pensamiento político moderno, la nación se asumió libre y creó un porvenir para realizar en él un proyecto histórico propio, centrado en el Estado independiente y en la nación soberana. A su vez, la transformación radical del presente y la creación de un horizonte abierto hacia el futuro modificaron la concepción que se tenía de la memoria de la nación.

La independencia política de España y la decisión de realizar un proyecto político nacional crearon un sujeto nuevo de la narración histórica: el Estado nacional. Por primera vez, en lugar de un territotio fragmentado y gobernado por poderes extraños, los mexicanos consideraron su país, las diferentes partes que lo integraban, su población y su pasado como una entidad unitaria. A partir de entonces, independientemente de las contradicciones internas, la nación se contempló como una entidad territorial, social y política que tenía un origen, un desarrollo en el tiempo y un futuro comunes. El surgimiento de una entidad política que integraba en sí misma las diferentes partes de la nación fue el nuevo sujeto de la historia que unificó la diversidad social y cultural de la población en una búsqueda conjunta de identidad nacional. ${ }^{47}$

\section{BIBLIOGRAFÍA}

-Alcina Franch, José, Arqueólogos o anticuarios. Historia antigua de la arqueología en la América española, Ediciones del Serbal, 1995.

-Arenas, Reinaldo, El mundo alucinante, Diógenes, 1969.

-Bernal, Ignacio, Historia de la arqueología en México, Editorial Porrúa, México, 1979.

47 Florescano, Memoria, 1994, pp. 520-522. 
-Boturini Benaduci, Lorenzo, Idea de una historia general de la América Septentrional, estudio preliminar de Miguel León Portilla, Editorial Porrúa, México, 1974.

-Bustamante, Carlos María de, Mañanas de la Alameda de México: publicadas para facilitar a las señoritas el estudio de la bistoria de su país, Valdés, México, 1835-1836, 2 vols.

-Brading, David A., Los orígenes del nacionalismo mexicano, Editorial Era, México, 1980.

-Castelán Rueda, Roberto, La fuerza de la palabra impresa. Carlos María de Bustamante y el discurso de la modernidad, Fondo de Cultura Económica, México, 1997.

-Clavijero, Francisco Javier, Antología, estudio introductorio de Gonzalo Aguirre Beltrán, Secretaría de Educación Pública, México, 1976.

-Cuadriello, Jaime, Maravilla americana. Variantes de la iconografía guadalupana, $\mathrm{Pa}-$ tronato Cultural de Occidente, 1984.

- "Los jeroglíficos de Nueva España" en Juegos de ingenio y agudeza. La pintura emblemática de la Nueva España, Museo Nacional de Arte, México, 1994.

"Visiones en Patmos Tenochtitlán: La mujer águila”, Artes de México, núm. 29, 1995, pp. 10-22.

-Florescano, Enrique e Isabel Gil Sánchez (comps.), Descripciones económicas regionales de Nueva España, Instituto Nacional de Antropología e Historia, México, 1976.

-Florescano, Enrique, Memoria mexicana, FCE, México, 1994.

- La bandera mexicana. Breve bistoria de su formación y simbolismo, Fondo de Cultura Económica, México, 1998.

-Gerbi, Antonello, La disputa del Nuevo Mundo. Historia de una polémica, 1750-1900, Fondo de Cultura Económica, México, 1960.

-Herrejón Morelos, Carlos, Antología documental, Secretaría de Educación Pública, México, 1985.
-Honour, Hugh, L'Amerique vue par l'Europe, Editions des Musees NationauxSecretariat d'Etat a la Culture, París, 1975.

-Humboldt, Alejandro de, Ensayo político sobre el reino de la Nueva España, edición de Juan A. Ortega y Medina, Porrúa, México, 1966.

-IMSS, El territorio mexicano, IMSs, México, 1982.

-Jiménez Codinach, Estela Guadalupe, México: su tiempo de nacer, 1750-1821, Fomento Cultural Banamex, México, 1997.

-Lemoine Villicaña, Ernesto, Morelos. Su vida revolucionaria a través de sus escritos y de otros testimonios de la época, Universidad Nacional Autónoma de México, México, 1985.

- Carlos María de Bustamante y su apologética historia de la revolución de 1810 , Dirección General de Difusión Cultural-Universidad Nacional Autónoma de México, México, 1984.

-Labastida, Jaime, Humboldt, ciudadano universal, Siglo Veintiuno Editores, México, 1999.

-Linati Claudio, Trajes civiles, militares $y$ religiosos de México, intr., estudio y trad. Justino Fernández, pról. Manuel Toussaint, Imprenta Universitaria, México, 1956.

-Millares Carlo, Agustín, Don Juan José de Eguiara y Eguren y su Bibliotheca mexicana, Universidad Nacional Autónoma de México, México, 1957.

-Miranda, José, Humboldt y México, Universidad Nacional Autónoma de México, México, 1962.

-Moreno Toscano, Alejandra, Geografía económica de México, siglo XVI, El Colegio de México, México, 1968.

-Mundy, Barbara E., The Mapping of New Spain. Indigenous Cartography and the Maps of the Relaciones Geograficas, The University of Chicago Press, 1996.

-Ocampo, Javier, Las ideas de un día. El pueblo mexicano ante la consumación de su independencia, El Colegio de México, México, 1969. 
-O'Gorman, Edmundo, Guía bibliográfica de Carlos Maria de Bustamante, Centro de Estudios de Historia de México, México, 1967.

-Orozco y Berra, Manuel, Apuntes para la bistoria de la geografía en México, Edmundo Aviña Levy editor, 1973.

-Ozouf, Mona, La fête révolutionnaire, 1789-1797, Gallimard, París, 1976.

-Pacheco, José Emilio, "La patria perdida (notas sobre Clavijero y la cultura nacional)" en Héctor Aguilar Camín, En torno a la cultura nacional, Instituto Nacional Indigenista, México, 1976.

-Riva Palacio, Vicente, México a través de los siglos, Ballescá y Cía. Editores, 1884-1889, 5 vols.

-Rodríguez, Jaime E., Mexico in the Age of Democratic Revolutions, 1750-1850, s.e., s. 1., 1994.

-Sacchi, Duccio, Mappe dal Nuovo Mondo. Cartografie locali e definizione del territorio in Nuova Spagna (secoli XVI-XVII), Franco-Angeli, 1997.
-Teresa de Mier, Servando, Historia de la revolución de Nueva España, antiguamente Anábuac, o verdadero origen y causas de ella con la relación de sus progresos hasta el presente año de 1813, Imprenta de la Cámara de Diputados, México, 1922, 2 vols. , Ideario político, prólogo, notas y cronología de Edmundo O'Gorman, Biblioteca Ayacucho, México, 1978.

-Vázquez de Knauch, Josefina Zoraida, Nacionalismo y educación de México, El Colegio de México, México, 1970.

-Villoro, Luis, Los grandes momentos del indigenismo en México, El Colegio de México, México, 1950.

- El proceso ideológico de la revolución de independencia, Universidad Nacional Autónoma de México, México, 1981.

, El proceso ideológico de la revolución de independencia, Secretaría de Educación Pública, México, 1986. 